OPEN ACCESS

Edited by:

Xianghui Guo,

Xiamen University, China

Reviewed by:

Tim Rixen,

Leibniz Centre for Tropical Marine

Research (LG), Germany

Birgit Gaye,

University of Hamburg, Germany

*Correspondence:

S. Wajih A. Naqvi

wnaqvi@iitk.ac.in

${ }^{\dagger}$ Present address:

S. Wajih A. Naqvi,

Department of Earth Sciences, Indian

Institute of Technology, Kanpur, India

Specialty section:

This article was submitted to

Marine Biogeochemistry,

a section of the journal

Frontiers in Marine Science

Received: 31 October 2020

Accepted: 21 January 2021

Published: 25 February 2021

Citation:

Naqvi SWA (2021) Deoxygenation in Marginal Seas of the Indian Ocean.

Front. Mar. Sci. 8:624322.

doi: 10.3389/fmars.2021.624322

\section{Deoxygenation in Marginal Seas of the Indian Ocean}

\author{
S. Wajih A. Naqvi*t \\ Council of Scientific \& Industrial Research, New Delhi, India
}

This article describes oxygen distributions and recent deoxygenation trends in three marginal seas - Persian Gulf and Red Sea in the Northwestern Indian Ocean (NWIO) and Andaman Sea in the Northeastern Indian Ocean (NEIO). Vertically mixed water column in the shallow Persian Gulf is generally well-oxygenated, especially in winter. Biogeochemistry and ecosystems of Persian Gulf are being subjected to enormous anthropogenic stresses including large loading of nutrients and organic matter, enhancing oxygen demand and causing hypoxia (oxygen $<1.4 \mathrm{ml} \mathrm{I}^{-1}$ ) in central and southern Gulf in summer. The larger and deeper Red Sea is relatively less affected by human activities. Despite its deep water having remarkably uniform thermohaline characteristics, the central and southern Red Sea has a well-developed perennial oxygen minimum at mid-depths. The available data point to ongoing deoxygenation in the northern Red Sea. Model simulations show that an amplified warming in the marginal seas of the NWIO may cause an intensification of the Arabian Sea oxygen minimum zone (OMZ). Increases in particulate organic carbon and decreases in oxygen contents of the outflows may also have a similar effect. In the Andaman Sea, waters above the sill depth $(\sim 1.4 \mathrm{~km})$ have characteristics similar to those in the Bay of Bengal, including an intense OMZ. As in the case of the Bay of Bengal, oxygen concentrations within the Andaman Sea OMZ appear to have declined slightly but significantly between early 1960s and 1995. The exceedingly isothermal and isohaline water that fills the deep Andaman Basin is also remarkably homogenous in terms of its oxygen content. A very slight but statistically significant decrease in oxygen content of this water also seems to have occurred over three decades preceding 1995. New information is badly needed to assess the extent of further change that may have occurred over the past 25 years. There have been some reports of coastal "dead zones" having developed in the Indian Ocean marginal seas, but they are probably under-reported and the effects of hypoxia on the rich and diverse tropical ecosystems - coral reefs, seagrasses, and mangroves in these seas remain to be investigated.

Keywords: deoxygenation, Indian Ocean, Red Sea, Persian Gulf, Andaman Sea, marginal seas

\section{INTRODUCTION}

The northern Indian Ocean is distinguished by several unusual oceanographic processes arising from its unique geographical setting. The presence of landmass that limits the Indian Ocean at rather low latitudes $\left(\sim 25^{\circ} \mathrm{N}\right)$ has a profound impact on its climate in the form of seasonally reversing winds - the monsoons. Regional geomorphology dominantly controls climate dynamics, 
particularly the distribution of monsoonal energy and rainfall, and the resultant variability of oceanographic processes. The contribution of orography (especially the presence of the Himalayas, Western Ghats, and East African Highlands) is crucial in this regard (e.g., Chakraborty et al., 2002). Also important is the eastward sloping of the Deccan Peninsula and the Ganges Basin (east of the Delhi Ridge) as a result of which most South Asian rivers flow into the Bay of Bengal (the Northeastern Indian Ocean, NEIO) and not into the Arabian Sea (the Northwestern Indian Ocean, NWIO). This creates a fresher, warmer surface layer and a very strong thermohaline stratification in the NEIO (Naqvi et al., 2006). Moreover, winds are generally weaker in the NEIO than in the NWIO, which in conjunction with the strong stratification prevents large-scale upwelling of cold subsurface waters, even along the eastern boundary (e.g., off Myanmar Naqvi et al., 2006). Together these processes create favorable conditions for large-scale deep convection in the atmosphere, providing positive feedback to rainfall (Shenoi et al., 2002), which is quite high in the NEIO. Consequently, the NEIO is a region of highly positive water balance (large excess of precipitation and runoff over evaporation). The situation is quite different in most of the NWIO, where strong southwesterly winds drive intense and large-scale upwelling (Naqvi et al., 2006), resulting in low sea surface temperatures (SSTs) during summer in the western Arabian Sea, greatly contributing to regional aridity. The freshwater runoff is very modest and the rainfall is scanty except along the west coast of India. As a result, except for a narrow belt in the eastern Arabian Sea, evaporation far exceeds precipitation and runoff (Prasad, 2004). The contrasting climatic and hydrographic conditions in the NWEO and NWIO are also reflected in oceanographic characteristics of the marginal seas, as described below.

Of the three marginal seas of the Indian Ocean, two (the Red Sea and Persian Gulf) are connected to the NWIO, while the third (the Andaman Sea) forms a part of the NEIO (Figure 1). The Mediterranean-type marginal seas of the NWIO have been fairly well investigated (Morcos, 1970; Grasshoff, 1975, 1976; Brewer and Dyrssen, 1985; Yao et al., 2014a,b; Al-Yamani and Naqvi, 2019). In comparison, oceanographic processes of the Andaman Sea are not so well known (Sen Gupta et al., 1981; Sarma and Narvekar, 2001; Jithin and Francis, 2020). All three marginal seas are connected to open ocean basins having some of the most intense mesopelagic oxygen minimum zones (OMZs) of the world oceans, although the redox status of these OMZs are quite different (Rao et al., 1994; Naqvi et al., 2006; Bristow et al., 2017). Utilizing historical and the most recent data available in public domain (Table 1), the present study investigates distributions of dissolved oxygen and current trends of deoxygenation in these basins.

\section{STUDY AREAS}

\section{Geological and Geographical Settings}

The marginal seas of the NWIO were formed as a result of tectonic movement of the Arabian Plate. The Arabian Plate began separating from the African Plate during the late Oligocene, $~ 25$ million years before present (Ma) (Stern and Johnson, 2010), creating the Red Sea, and as the Arabian Plate collided with the Eurasian Plate, the Persian Gulf was formed during the early Miocene (23-16 Ma) (Allen et al., 2004). The two basins are quite different in terms of the geomorphology. The Red Sea is $\sim 1,930 \mathrm{~km}$ long, extending in the SSE-NNW direction from the Strait of Bab-el-Mandeb (latitude $12.58^{\circ} \mathrm{N}$, longitude $43.33^{\circ} \mathrm{E}$ ) up to latitude $\sim 28^{\circ} \mathrm{N}$, where it bifurcates into the Gulf of Suez and the Gulf of Aqaba. It is on an average $\sim 280 \mathrm{~km}$ wide, and measures $\sim 438,000 \mathrm{~km}^{2}$ in area (Morcos, 1970). Much of the Red Sea is comprised of shallow shelves, but the central axial trough is quite deep, reaching a maximum depth of $\sim 3,000 \mathrm{~m}$; the average depth is $491 \mathrm{~m}$ (Morcos, 1970). The Red Sea is a silled basin connected to the Gulf of Aden through the Strait of Bab-el-Mandeb where the maximum depth is $160 \mathrm{~m}$ according to Sofianos and Johns (2007) and $137 \mathrm{~m}$ according to Lambeck et al. (2011).

Like the Red Sea, the Persian Gulf is also almost completely land-locked, having only a narrow connection to the Arabian Sea through the Gulf of Oman at the Hormuz Strait (latitude $26.6^{\circ} \mathrm{N}$, longitude $56.25^{\circ} \mathrm{E}$ ); however, unlike the Bab-el-Mandeb the Hormuz Strait does not have a sill. The Persian Gulf is bounded in the northwest by the Tigris-Euphrates Delta at $\sim 30^{\circ} \mathrm{N}$ latitude, in the east by Iran and in the west by the Arabian Peninsula. The Persian Gulf basin is wedge-shaped. It is about $1,000 \mathrm{~km}$ long, but with a maximum width of $336 \mathrm{~km}$, the total area of the Persian Gulf is only $251,000 \mathrm{~km}^{2}$ (Sheppard et al., 2010). With reference to the main axis the bottom topography of the Persian Gulf is highly asymmetrical with a steep slope on the Iranian side and a very gentle slope on the Arabian side. Thus, the deepest part of the Persian Gulf is off the Iranian coast, but even here the water depth does not exceed $\sim 90 \mathrm{~m}$. The average depth of the Persian Gulf is only $36 \mathrm{~m}$, and so, in spite of a fairly large area, the total volume of the Persian Gulf is only $\sim 8,600 \mathrm{~km}^{3}$ (Sheppard et al., 2010 ) about $1 / 27$ of the volume of the Red Sea $\left(\sim 233,000 \mathrm{~km}^{3}\right)$ (Morcos, 1970).

The Andaman Sea extends $\sim 1,250 \mathrm{~km}$ from Myanmar to Sumatra (Indonesia). This basin was formed by the oblique converging boundaries of the Indian Oceanic Plate and South East Asian Plate, a process that started in the early Cretaceous and is still ongoing (Scaife et al., 2010). The Andaman-Nicobar island arc created during this process bounds the basin in the west. Due to the complex tectonics the bottom topography is quite rugged (Cochran, 2010). The East Basin is the largest and deepest basin of the Andaman Sea where the maximum depth exceeds 4,200 m. To the north and east of this basin lies the broad continental shelf of Myanmar and Thailand, with the Irrawaddy Delta in the north being another prominent geographical feature. The average depth of the Andaman Sea is 1,096 m. ${ }^{1}$ However, the connection with the Bay of Bengal through the deepest saddle in the Andaman-Nicobar Ridge is only $\sim 1,400 \mathrm{~m}$ deep at the Great Passage (as determined by the divergence of vertical

\footnotetext{
${ }^{1}$ http://bse.sci-lib.com/article057639.html
} 

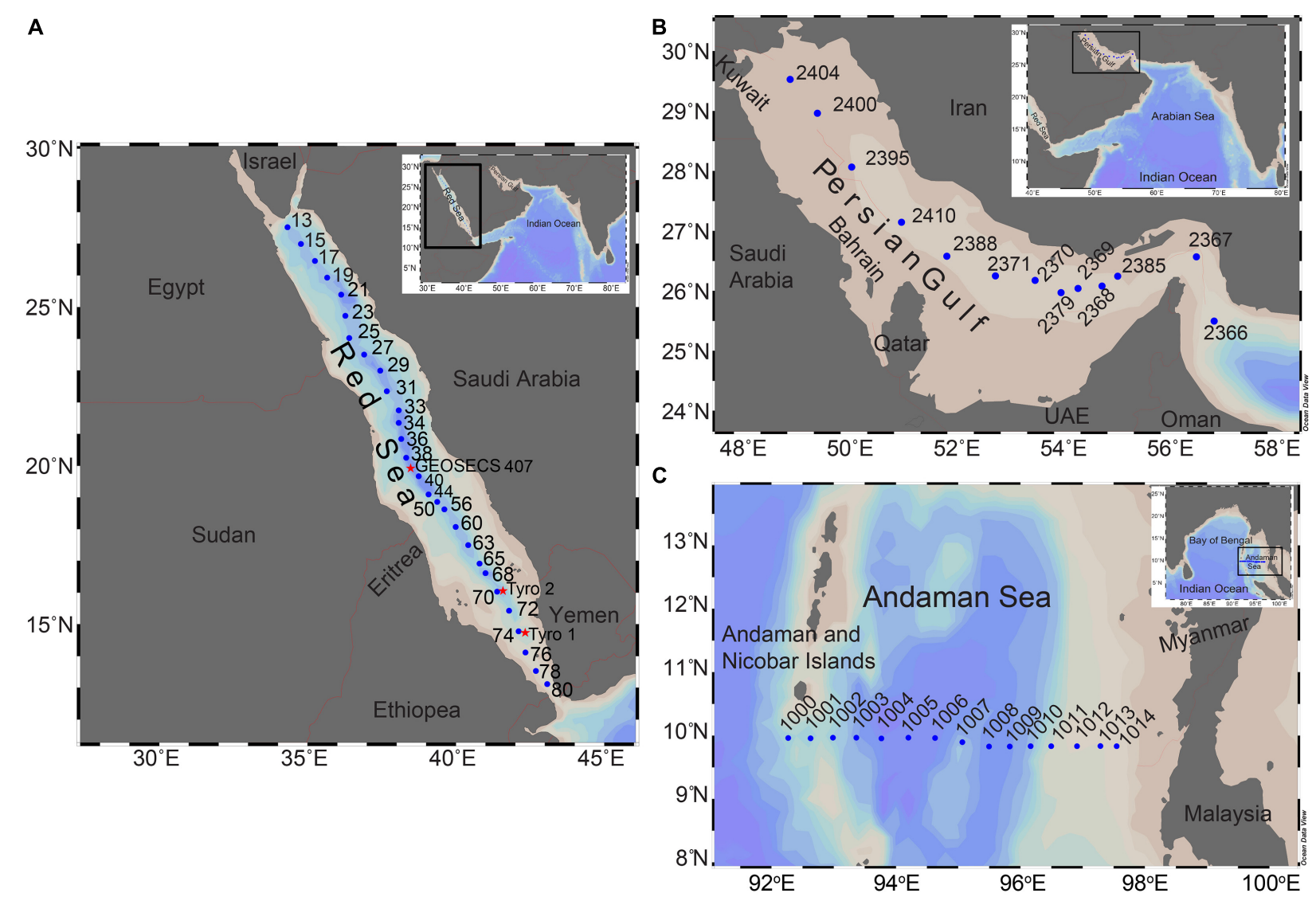

FIGURE 1 | The marginal seas of the Indian Ocean and locations of stations constituting vertical sections presented in Figures 2, 4, 5: (A) Red Sea, R.V. Sagar Kanya cruise in May 1983 (black symbols); (B) Persian Gulf, R.V. Atlantis // cruise in February 1977; and (C) Andaman Sea, R.V. Knorr cruise in October 1995. The red symbols in (A) denote locations of GEOSECS Station 407 and the two Tyro stations data from which are compared with Sagar Kanya data in Figure 3.

profiles of temperature within and just outside the Andaman Basin - Naqvi et al., 1994).

\section{Hydrography and Oxygen Distribution}

As stated above, the Red Sea and the Persian Gulf on one hand and the Andaman Sea on the other are located in contrasting climatic regimes. Moreover, unlike the Andaman Sea, the Red Sea, and the Persian Gulf are almost land locked. Evaporation rates in both basins are exceedingly high $\left(>2 \mathrm{~m} \mathrm{year}^{-1}\right)$ while rainfall is negligible (Sofianos et al., 2002; Sheppard et al., 2010). While the Red Sea does not receive any river runoff, some freshwater flow does occur into the Persian Gulf, although it is quite modest $\left(35-133 \mathrm{~km}^{3}\right.$ year-1) and restricted to the northwestern region, mainly from the Shatt al-Arab River which carries the combined flows from the Tigris, Euphrates, and Karun rivers (Sheppard et al., 2010). The resultant Mediterranean-type (anti-estuarine) exchanges (near surface inflow and near-bottom outflow) between the Red Sea and the Persian Gulf with the Gulf of Aden and Gulf of Oman, respectively, are primarily driven by the highly negative water balance. That is, in order to compensate for the net loss of water within these basins, there is inflow of fresher waters from the Gulf of Aden and the Gulf of Oman. However, these inflows also bring in salt, and in order to maintain the salt balance, there must also be export of more saline waters out of these basins. This mostly occurs close to the bottom by outflowing currents through the Straits of Bab-el-Mandeb and Hormuz. Estimates of respective inflows and outflows are $\sim 12,620 \mathrm{~km}^{3}$ year ${ }^{-1}$ and $11,680 \mathrm{~km}^{3}$ year ${ }^{-1}$ for the Red Sea (Murray and Johns, 1997), and 7,250 km year $\mathrm{km}^{-1}$ and $6,620 \mathrm{~km}^{3}$ year $^{-1}$ for the Persian Gulf (Sheppard et al., 2010). Circulation in the Hormuz Strait is two layered: surface water from the Gulf of Oman flows in through the northern part of the strait, although a part of it re-circulates and flows out through the southern part, while the dense, high-salinity water exits the Persian Gulf close to the bottom throughout the year with little seasonal variability (Johns et al., 2003; Pous et al., 2015). A twolayer circulation also prevails in the Bab-el-Mandeb Strait for most parts of the year, but in the summer (June-September) northwesterly winds drive weak outflow at the surface while strong intrusion of Gulf of Aden Intermediate Water (GAIW) occurs at mid-depth above the greatly weakened outflowing current close to the bottom (Maillard and Soliman, 1986; Murray and Johns, 1997; Sofianos et al., 2002; Sofianos and Johns, 2007; Yao et al., 2014a). The outflows from the Red Sea and the Persian Gulf, easily distinguished by prominent salinity maxima, spread widely across the NWIO with their cores located around 27.2 and 
TABLE 1 | Sources of data.

\begin{tabular}{|c|c|c|c|}
\hline \multicolumn{4}{|l|}{ Red Sea } \\
\hline Vessel/platform, project/program & Period & $\begin{array}{l}\text { Data availability } \\
\text { URL }\end{array}$ & Remarks/reference \\
\hline $\begin{array}{l}\text { R.V. Melville } \\
\text { GEOSECS Indian Ocean Leg } 4\end{array}$ & December 1977 & $\begin{array}{l}\text { https://epic.awi.de/id/eprint/34721/1/ } \\
\text { indian-exped_geosces.pdf }\end{array}$ & Weiss et al., 1983 \\
\hline $\begin{array}{l}\text { R.V. Sagar Kanya } \\
\text { Test Trial III Cruise }\end{array}$ & May 1983 & https://did.nio.org/ & $\begin{array}{l}\text { Sections unpublished, but data } \\
\text { used by Naqvi et al. (1986) }\end{array}$ \\
\hline $\begin{array}{l}\text { R.V. Tyro } \\
\text { Cruises } 43 \text { and } 52 \\
\text { Netherlands Indian Ocean Program }\end{array}$ & May 1992, February 1993 & $\begin{array}{l}\text { National Centers for Environmental } \\
\text { Information, National Oceanic and } \\
\text { Atmospheric Administration (NOAA) } \\
\text { https://www.nodc.noaa.gov }\end{array}$ & \\
\hline $\begin{array}{l}\text { Argo floats } \\
\# 6901573 \# 6901577 \\
\text { EURO-ARGO }\end{array}$ & $\begin{array}{l}\text { September 29, 2015-February 19, } \\
2017 \\
\text { September 30, 2015-December } \\
29,2016\end{array}$ & $\begin{array}{l}\text { http://www.ifremer.fr/co-argoFloats/float? } \\
\text { ptfCode=6901573\&lang=en \penalty- } \ @ M \\
\text { http://www.ifremer.fr/co-argoFloats/float? } \\
\text { ptfCode=6901577\&lang=en }\end{array}$ & \\
\hline \multicolumn{4}{|l|}{ Persian Gulf } \\
\hline Vessel, project/program & Period & $\begin{array}{l}\text { Data availability } \\
\text { URL }\end{array}$ & Remarks/reference \\
\hline $\begin{array}{l}\text { R.V. Lesnoye } \\
\text { Cruise } 188\end{array}$ & September 1968 & https://www.nodc.noaa.gov & Al-Said et al., 2018 \\
\hline $\begin{array}{l}\text { R.V. Atlantis // } \\
\text { Cruise } 2968\end{array}$ & February 1977 & https://www.nodc.noaa.gov & $\begin{array}{l}\text { Brewer et al., 1978; Brewer and } \\
\text { Dyrssen, } 1985\end{array}$ \\
\hline R.V. Mukhtabar al-Bahr & $\begin{array}{l}\text { September-October } 2000 \\
\text { February-March } 2001\end{array}$ & & Read from: Al-Ansari et al., 2015 \\
\hline KISR's research boats & July 19, 2011, April 30, 2017 & & $\begin{array}{l}\text { Al-Yamani et al., 2020; raw data } \\
\text { provided by Faiza Al-Yamani }\end{array}$ \\
\hline \multicolumn{4}{|l|}{ Andaman Sea } \\
\hline Vessel project/program & Period & $\begin{array}{l}\text { Data availability } \\
\text { URL }\end{array}$ & Remarks/reference \\
\hline $\begin{array}{l}\text { R.V. Vityaz } \\
\text { Cruise } 9506 \\
\text { International Indian Ocean Expedition (IIOE) }\end{array}$ & March 1961 & https://www.nodc.noaa.gov & \\
\hline $\begin{array}{l}\text { U.S.S. Serrano } \\
\text { Cruise } 545 \\
\text { IIOE }\end{array}$ & November-December 1961 & https://www.nodc.noaa.gov & Cast 55 data suspect; not included \\
\hline $\begin{array}{l}\text { U.S.S. Serrano } \\
\text { Cruise } 90 \\
\text { IIOE }\end{array}$ & March 1963 & https://www.nodc.noaa.gov & \\
\hline $\begin{array}{l}\text { I.N.S. Kistna } \\
\text { Cruise } 414 \\
\text { IIOE }\end{array}$ & September 1963 & https://www.nodc.noaa.gov & Only Cast 212 data included \\
\hline $\begin{array}{l}\text { R.V. Kushi Maru } \\
\text { Cruise } 30184 \\
\text { IIOE }\end{array}$ & November 1963 & https://www.nodc.noaa.gov & \\
\hline $\begin{array}{l}\text { R.V. Pioneer } \\
\text { Cruise } 201 \\
\text { IIOE }\end{array}$ & April 1964 & https://www.nodc.noaa.gov & \\
\hline $\begin{array}{l}\text { I.N.S. Kistna } \\
\text { Cruise } 409 \\
\text { IIOE }\end{array}$ & August 1964 & https://www.nodc.noaa.gov & Only Cast 309 data included \\
\hline $\begin{array}{l}\text { R.V. Knorr } \\
\text { Cruise } 14517 \\
\text { World Ocean Circulation Experiment } \\
\text { (WOCE) }\end{array}$ & October 1995 & https://www.nodc.noaa.gov & Talley, 2013 \\
\hline
\end{tabular}

$26.5 \sigma_{\theta}$ surfaces (Wyrtki, 1971). They play an important role in mesoplelagic water mass structure and biogeochemical cycling in the NWIO (Naqvi et al., 2006). Dense waters within the two seas, from which these outflows originate, are formed through cooling of high-salinity waters in winter. In the Red Sea this happens in the northern extreme of the Red Sea proper and in the Gulf of Suez and Gulf of Aqaba (Wyrtki, 1974). While the upper deep water (above $\sim 300 \mathrm{~m}$ ), which is the source of the 
outflow, is formed in the northern Red Sea (Cember, 1988; Yao et al., 2014b), the deeper waters are supplied by the two gulfs (Woelk and Quadfasel, 1996; Plahn et al., 2002).

Despite the very similar geographical and climatic settings there are three important depth-related hydrographic differences between the Red Sea and the Persian Gulf: (1) The Persian Gulf is far more rapidly ventilated (renewal time $\sim 1.2$ year Al-Said et al., 2018) than the Red Sea (renewal time 36 years according to Cember (1988), and 40-90 years according to Woelk and Quadfasel (1996); (2) water column in the Persian Gulf is, in general, vertically well mixed; and (3) seasonality is far more pronounced throughout the Persian Gulf as reflected by the very wide SST range $\left(\sim 12-35^{\circ} \mathrm{C}-\mathrm{Al}\right.$-Yamani et al., 2004; Al-Said et al., 2018).

Distributions of temperature, salinity and dissolved oxygen along the main axes of the Red Sea and the Persian Gulf are presented in Figures 2, 4, respectively. While the data from the Red Sea were collected by the author on board R.V. Sagar Kanya in May 1983, those from the Persian Gulf were generated during a cruise of R.V. Atlantis II in February 1977 (Brewer et al., 1978; Brewer and Dyrssen, 1985). Despite marked seasonal changes that are known to occur, especially in the Persian Gulf, these data adequately describe main features of hydrography and spatial oxygen variability in the two seas, and highlight their depth-dependent differences.

As the Sagar Kanya observations were made in early summer, the effect of winter cooling could still be seen in lower SSTs and relatively weaker thermocline near the northern end of the transect, close to the formation zones of deep waters. The isothermal and isohaline character of deep water is evident from the temperature and salinity panels (Figure 2 ). The mean values ( \pm SD) for temperature and salinity at depths $\geq 400 \mathrm{~m}$ at and south of Station 25 are $21.709 \pm 0.035$ and $40.569 \pm 0.019^{\circ} \mathrm{C}$, respectively, with a $\sigma_{\theta}$ value of $\sim 28.59$. In fact, the deep water in the Red Sea is warmer and more saline than in any other marine basin (WOA-18 ${ }^{2}$ ). Despite the remarkably uniform thermohaline characteristics, oxygen concentrations are not uniformly distributed within this layer. Instead, the Red Sea exhibits a typical mid-depth oxygen minimum observed in most other parts of the ocean (Figure 2). The oxygen distribution pattern is similar to that reported by Sofianos and Johns (2007), except that the minimum associated with the intruding GAIW with its core around $75 \mathrm{~m}$, reported by these authors, is not seen in the Sagar Kanya data. This is consistent with the observations of Murray and Johns (1997) in terms of the timing of initiation of the GAIW intrusion. Subsurface oxygen concentrations generally decrease southward from the source regions of deep water, but the distribution is somewhat patchy, arising from the complex balance between supply and consumption. One would expect respiration, fuelled by organic matter exported from the euphotic zone, to be important in controlling the intensity of the oxygen minimum. Going by the chlorophyll distribution, the southern extreme of the Red Sea is more productive than the central and northern parts (Brewin et al., 2015), and as it is also most downstream of the deep water flow, the oxygen minimum is

${ }^{2}$ https://www.nodc.noaa.gov/OC5/woa18/ expected to be the most intense in the southern Red Sea. Such is not exactly the case. However, it must be pointed out that the deep central axis of the Red Sea is a relatively narrow and elongated feature (Figure 1A). In such a system benthic processes are expected to substantially influence water column characteristics through lateral exchanges/mixing, and this might contribute to the observed slight deviation of oxygen distribution from the expected trend. Moreover, the presence of eddies (Sofianos and Johns, 2003, 2007; Yao et al., 2014b) might also cause the observed patchiness.

In order to check the representativeness of the Sagar Kanya data, oxygen profiles from three selected Sagar Kanya stations are compared in Figure 3 with those from nearby sites sampled on other cruises (SK Station 40 with GEOSECS 407, sampled on board R.V. Melville on December 22, 1977; SK Stations 70 and 74 with two stations sampled on board R.V. Tyro during the Netherlands Indian Ocean Program on February 03, 1993 and May 27, 1992, respectively). Although sampled over 5 years apart and in different seasons, the GEOSECS 407 and SK Station 40 profiles are remarkably similar. The Sagar Kanya data also compare well with the Tyro data collected 9 years later, indicating that oxygen distribution seen in Figure 2 is typical of the Red Sea.

Observations in the Persian Gulf (Figure 4) show weak or no thermal stratification. This is because of low atmospheric temperatures and shallow depths ensure vertical mixing throughout the water column. However, the density does increase with depth. As the Persian Gulf basin is not separated by a sill, the Gulf Deep Water formed along the coasts of Kuwait and UAE is not topographically confined. The highest densities ( $\sigma_{\theta}$ reaching up to 29.856 ) occurred off UAE on this cruise. In comparison the maximum $\sigma_{\theta}$ value off Kuwait was 29.36 (wintertime density has increased greatly off Kuwait in recent years Al-Said et al., 2018). The highest density in the deepest part of the Persian Gulf in the south was slightly lower $\left(\sigma_{\theta} 29.159\right.$ at $76 \mathrm{~m}$ at Station 2368), but the near-bottom densities were quite variable $\left(\sigma_{\theta}\right.$ 28.388-29.36 north of Station 2385) along the transect. However, as in the case of the Red Sea Outflow, the density of water that flows out of the Persian Gulf and spreads into the Gulf of Aden and then in the Arabian Sea is much lower $\left(\sigma_{\theta} 26.5\right.$ Wyrtki, 1971), reflecting modification of this watermass through mixing in the Hormuz Strait region (Swift and Bower, 2003). Considering the above-mentioned estimates of the volumes of water within the Persian Gulf and of the outflows and inflows, the flushing time of Persian Gulf is just over 1 year (Al-Said et al., 2018), and this is reflected by the well-oxygenated conditions prevailing in the water column. There is one other data set with basin-wide oxygen measurements made on a cruise of F.S. Meteor in the Persian Gulf slightly later in the year (MarchApril 1965), that shows similar distribution pattern (Grasshoff, 1976). Oxygen concentrations below $70 \%$ saturation at mid depths in the southern Gulf were observed on this occasion. At one station located in the central Gulf off Iran, however, a single near-bottom sample had $1.84 \mathrm{ml} \mathrm{l}^{-1} \mathrm{O}_{2}(82.11 \mu \mathrm{M})$, $\sim 36 \%$ of the saturation value; at two other nearby stations the observed oxygen depletion was more moderate $(<80 \%)$. Later, in September 1986, minimum oxygen concentrations ranging between 1.2 and $2.0 \mathrm{ml} \mathrm{l}^{-1}(53.55-89.25 \mu \mathrm{M})$ were measured 


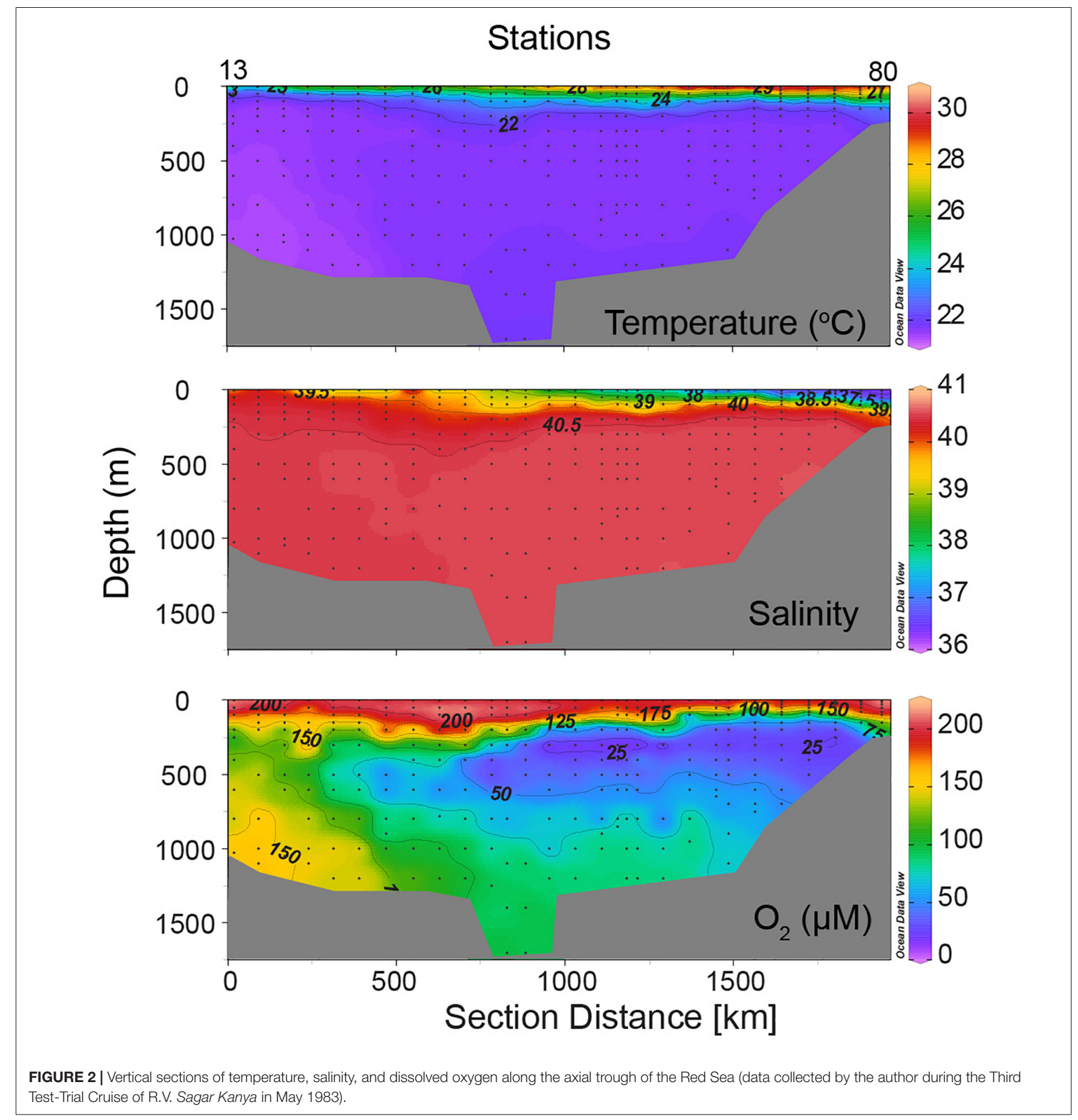

during a cruise of R.V. Mukhtabar al-Bahr in the southeastern Gulf (El Samra and El Gindy, 1990), and Hashimoto et al. (1998) found even lower oxygen concentrations during the cruise of R.V. Umitaka-Maru - $1.12 \mathrm{ml} \mathrm{l}^{-1}(49.98 \mu \mathrm{M})$ in December 1993 and $1.00 \mathrm{ml} \mathrm{l}^{-1}(44.62 \mu \mathrm{M})$ - in December 1994. Unfortunately, other than the observations to be described later that were made on board the Russian Research Vessel Lesnoye in the summer of 1968 , there are no basin-wide oxygen data in the global data base from the Persian Gulf for peak summer.
The hydrography of the Andaman Sea is greatly influenced by (a) large runoff from the Irrawaddy River that, like other parts of the NEIO, creates a low-salinity surface layer resulting in strong thermohaline stratification (Naqvi et al., 2006), and (b) the isolation of deep waters by the Andaman-Nicobar Ridge below the sill depth $(\sim 1,400 \mathrm{~m})$. As a result, the deep and bottom waters cannot flow into the Andaman Basin, and the water throughout the basin below the sill depth is derived from the Bay of Bengal from the sill depth, and so the thermohaline characteristics of 


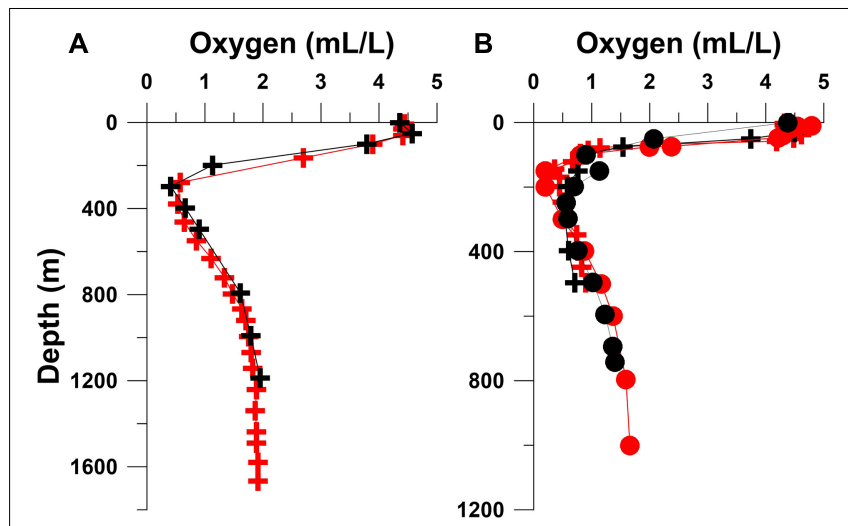

FIGURE 3 | Comparison of oxygen profiles from selected Sagar Kanya (SK) stations with those from nearby stations occupied during other cruises: (A) SK Station 40 (black crosses) sampled on May 24, 1983 with GEOSECS Station 407 (red crosses) sampled on December 22, 1977; (B) SK Station 70 (black circles) sampled on May 29, 1983 with Tyro Station 1 (red circles) sampled on May 27, 1992, and SK Station 74 sampled on May 29, 1983 (black crosses) with Tyro Station 2 (red crosses) sampled on February 03, 1993. See

Figure 1 for station locations.

water at depths exceeding $2 \mathrm{~km}$ are extraordinarily homogenous. Observations along a zonal $\left(\sim 10^{\circ} \mathrm{N}\right)$ transect in the Andaman Sea made during a cruise of R.V. Knorr in October 1995 (Figure 5) show a potential temperature range of 4.693-4.761 (mean $\pm \mathrm{SD}=4.73 \pm 0.014$ ), and a salinity range of 34.85434.861 (mean $\pm \mathrm{SD}=34.860 \pm 0.001$ ) with a highly invariable $\sigma_{\theta}$ of $27.595 \pm 0.001$. Just outside the Andaman Sea in the Bay of Bengal this density surface is found at $\sim 1.4 \mathrm{~km}$, and so this should be the sill depth at the Great Passage.

It has been proposed recently that the rate of tide-induced vertical mixing in deep waters of the Andaman Sea is about two-orders of magnitude higher than that in the Bay of Bengal and that this may contribute to downward diffusion of heat in the Andaman Sea, in part accounting for the high deepwater temperature (Jithin and Francis, 2020). However, it must be pointed out that the greatly enhanced vertical mixing is by itself a consequence of the lack of vertical stratification below the sill depth in the Andaman Sea, thereby making the proposed mechanism secondary.

The strong thermohaline stratification resulting from freshwater runoff by the Irrawaddy is seen in Figure 5, which also shows the absence of upwelling over the shelf in the eastern Andaman Sea, typical of the eastern boundaries of the Pacific and Atlantic Oceans at comparable latitudes. The regional OMZ of the NEIO is present below the pycnocline, but unlike the eastern boundaries of the North and South Pacific and South Atlantic where oxygen concentrations within the OMZ often fall below the detection limit of even the highly sensitive STOX oxygen sensors accompanied by the accumulation of nitrite indicating microbial reduction of nitrate (e.g., Thamdrup et al., 2012), such "functional anoxia" does not occur in the Andaman Sea. In fact, the minimum recorded oxygen concentration was slightly lower $\left(15.6 \mu \mathrm{M} \mathrm{O}_{2}\right.$ at $149 \mathrm{~m}$, Station 1000) at the eastern end of the transect (close to the Ten-Degree Channel) than that measured over the Myanmar-Thailand shelf $(22.9 \mu \mathrm{M}$ at $217 \mathrm{~m}$, Station 1013). What prevents the OMZ of the NEIO from turning fully anoxic (supporting vigorous reductive loss of combined nitrogen) is still not fully understood (Rao et al., 1994; Bristow et al., 2017). One possible explanation is that ballast provided by the terrigenous mineral particles rapidly removes particulate organic matter from the water column to the seafloor with little pelagic degradation (Ittekkot et al., 1992; Rao et al., 1994; Naqvi et al., 1996; Rixen et al., 2019). Anomalous near-bottom anomalies in oxygen and nutrients in the Bay of Bengal (Broecker et al., 1980; Mantyla and Reid, 1995) have been taken as a proof of relatively fresh organic matter reaching the seafloor in the NEIO. Consequently, one should expect significant oxygen depletion in the deep Andaman Basin. Clearly, such is not the case. The remarkably uniform oxygen concentrations (77.9-80.67 $\mu \mathrm{M}$, mean $\pm \mathrm{SD}=79.06 \pm 0.69$ at depths $>2 \mathrm{~km}$ along the Knorr section) are intriguing. These are consistent with the observations of Naqvi et al. (1994) who reported the apparent oxygen utilization (AOU) at depths $>1.3 \mathrm{~km}$ in the Andaman Sea $(239 \pm 2 \mu \mathrm{M})$ to be the same as the AOU at $1.3 \mathrm{~km}$ just outside the Andaman Sea in the Bay of Bengal, leading them to conclude that the renewal of deep waters in the Andaman Sea is rapid, with minimal chemical changes occurring during the residence of water below the sill depth.

\section{RECENT DEOXYGENATION TRENDS IN OFFSHORE WATERS}

In this section, the most recent oxygen data from the three marginal seas are compared with reliable historical data available in the global data base to extract trends of the ongoing deoxygenation. All but one of the data sets used here were generated following the classical Winkler procedure, the principle of which has remained essentially unchanged since its introduction in the late 19th century (Winkler, 1888). Modified applications of this technique for seawater dissolved oxygen measurements since the 1960s claim an accuracy of 0.1\% (Carpenter, 1965). While earlier Winkler titrations involved manual titrations with visual end-point detection using starch as the indicator, automated titrations are increasingly being used in recent times. The two techniques give very similar results except when oxygen levels approach zero, and manual titrations yield somewhat higher values (by $\sim 0.04 \mathrm{ml} \mathrm{l}^{-1}, 1.8 \mu \mathrm{M}$ - Banse et al., 2014). Only one data set used here, viz. from the $1995 \mathrm{Knorr}$ cruise in the Andaman Sea was obtained with the automated measurements. The Argo float data, used in the case of Red Sea, are relatively less accurate, but with the existing protocol for oxygen optode calibration and correction of any drift the accuracy of float data is still within 1\% (Bettig and Körtzinger, 2015). The shifts in oxygen levels being reported here are well beyond these uncertainties.

\section{Red Sea}

There is a dearth of recent information from the Red Sea in the available global databases to assess the ongoing deoxygenation trends in the region, except for the high-density profiles 


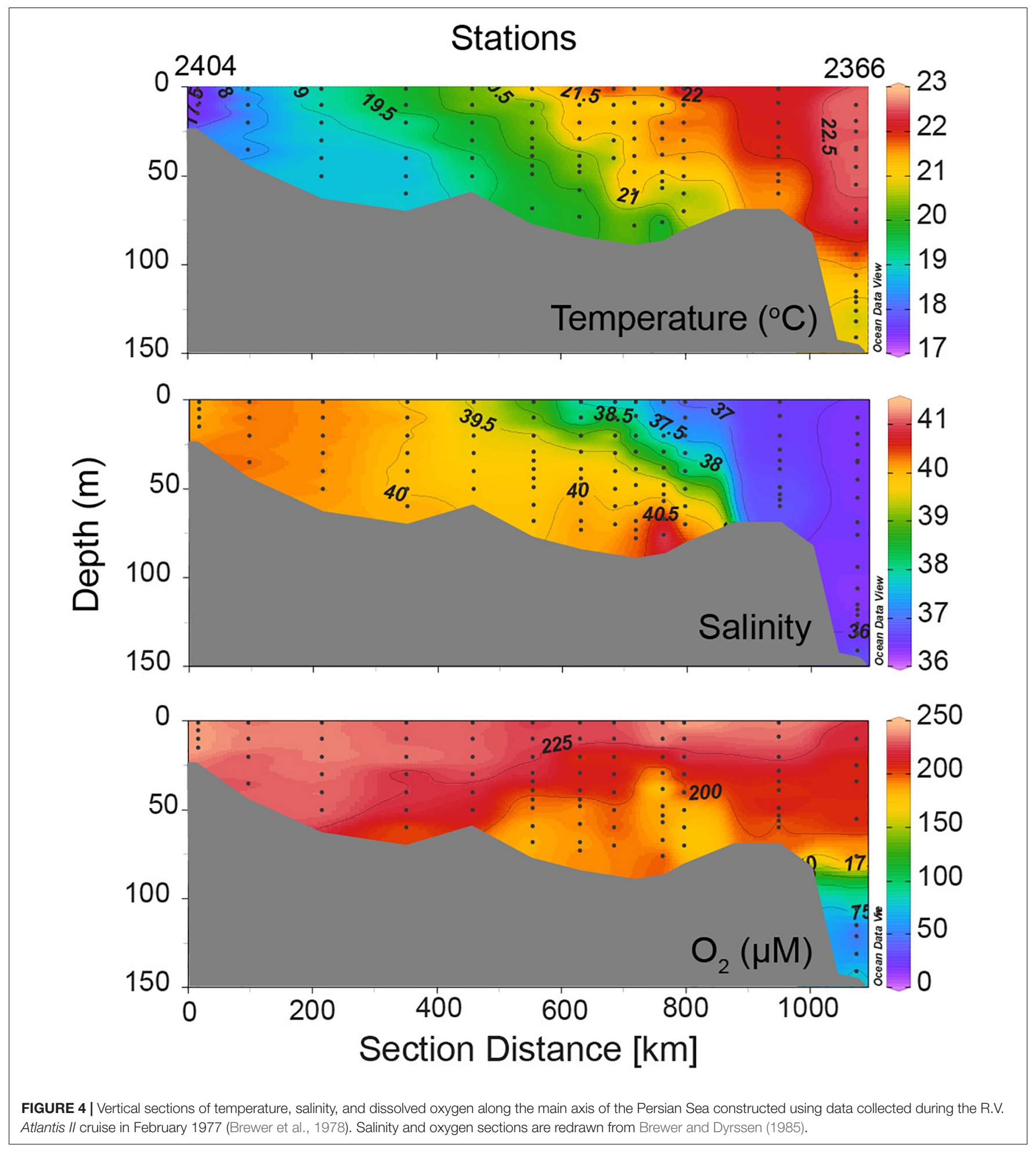

generated by two Argo floats north of $\sim 23^{\circ} \mathrm{N}$ latitude (Table 1). While one of these floats operated from September 29, 2015 to February 19, 2017, the other was active from September 30, 2015 to December 29, 2016. A comparison of the data from these floats with those generated north of $23^{\circ} \mathrm{N}$ latitude during the above-mentioned cruise of R.V. Sagar Kanya (up to Station 29 - Figure 2) is made in Figure 6 (modified from Naqvi, 2019). While the Sagar Kanya data provide a snapshot of the conditions prevailing at the time of the cruise, the float data covered a period well beyond an annual cycle at a very high resolution. Despite the seasonal cooling in the northern Red Sea and in the Gulfs of Aqaba and Suez, which lead to convection and 


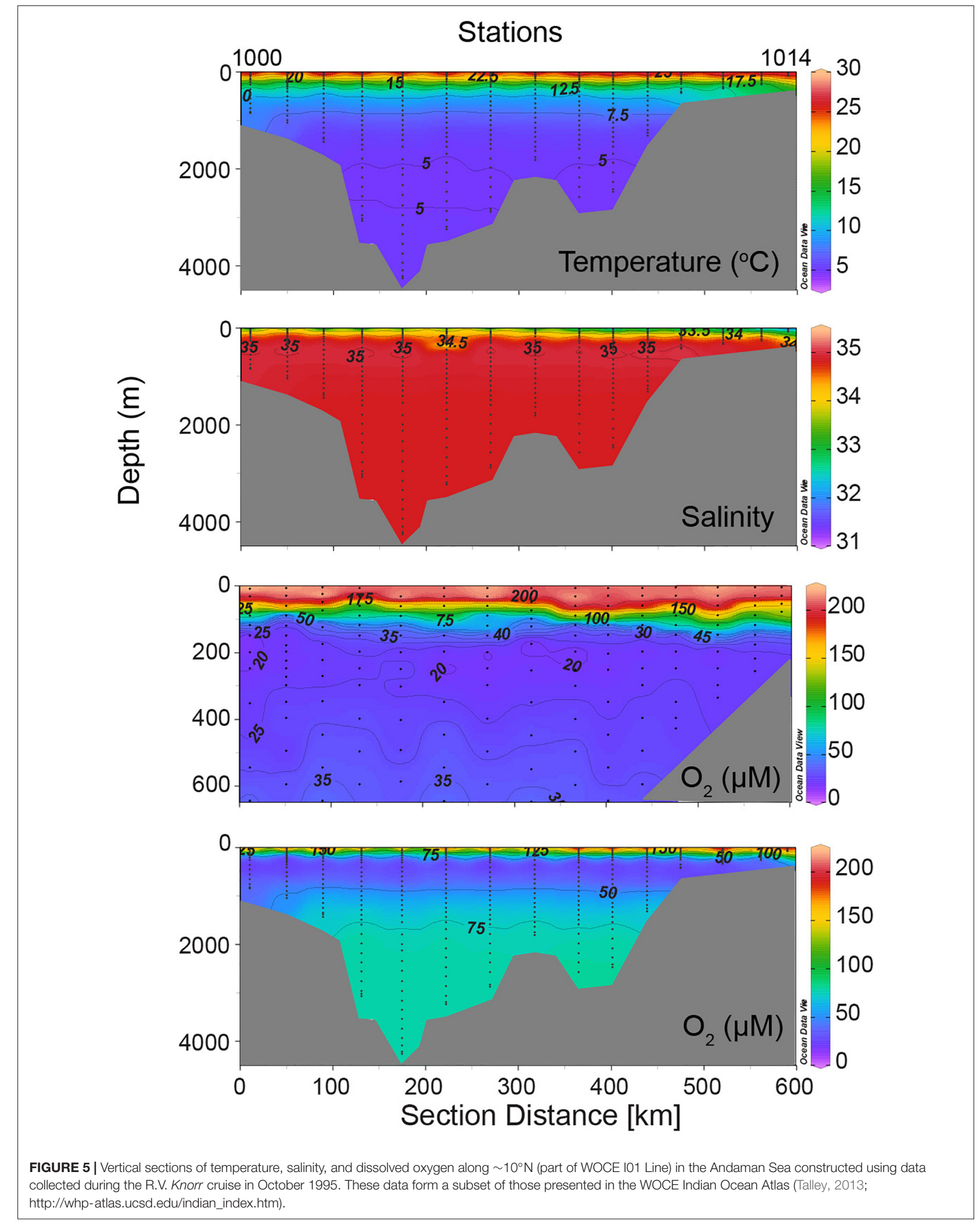




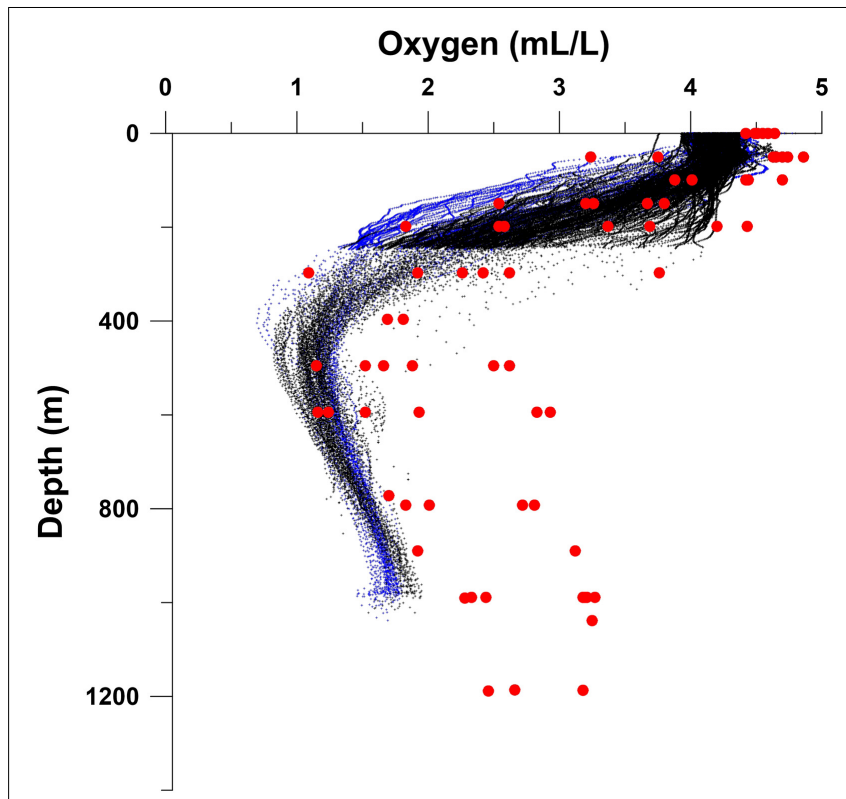

FIGURE 6 | Comparison of oxygen profiles generated by two Argo floats deployed in the Red Sea north of $\sim 23^{\circ} \mathrm{N}$ latitude: \#6901573 from September 29, 2015 to February 19, 2017 (black symbols) and \#6901577 from September 30, 2015 to December 29, 2016 (blue symbols) with the Winkler oxygen data (red circles) collected during the May 1983 cruise of R.V. Sagar Kanya (Figures 1A, 2).

deep water formation, the float data are fairly tightly clustered, with good overlapping of values from the two floats. In addition to the seasonal change, geographical variability - southward decrease in oxygen seen in Figure 2 - would also contribute to the spread seen in Figure 6. Even considering this scatter, oxygen concentrations recorded by the floats during 2015-2017 were generally much lower than those measured on the Sagar Kanya cruise, especially in deeper water (below $400 \mathrm{~m}$ ). As the concentration shift, most pronounced at the northern stations, far exceeds any potential error in the float data it may be concluded that substantial deoxygenation has occurred the Red Sea over the past three decades.

\section{Persian Gulf}

Substantial seasonal changes in oxygen distribution are expected to occur in the Persian Gulf due to wide temperature range. Results of Grasshoff (1976) and Brewer and Dyrssen (1985) (Figure 4) showed that the water column is vertically well-mixed and well-oxygenated during winter almost everywhere. However, an oxycline may develop in the deeper parts of the central and southern Gulf during summer due to warming of surface waters. This is evident from the contrasting profiles (Figure 7) at a station located close to the northern edge of the Qatar's EEZ that was sampled in late summer (September-October, 2000) and winter (February-March, 2001) (Al-Ansari et al., 2015). While the bottom-water oxygen concentration was $\sim 90 \%$ of the saturation value in winter, the saturation level fell to $\sim 18 \%$ in summer with the lowest recorded concentration of $0.86 \mathrm{ml} \mathrm{l}^{-1}$ $(38.38 \mu \mathrm{M})$. In order to resolve the seasonality from the decadal

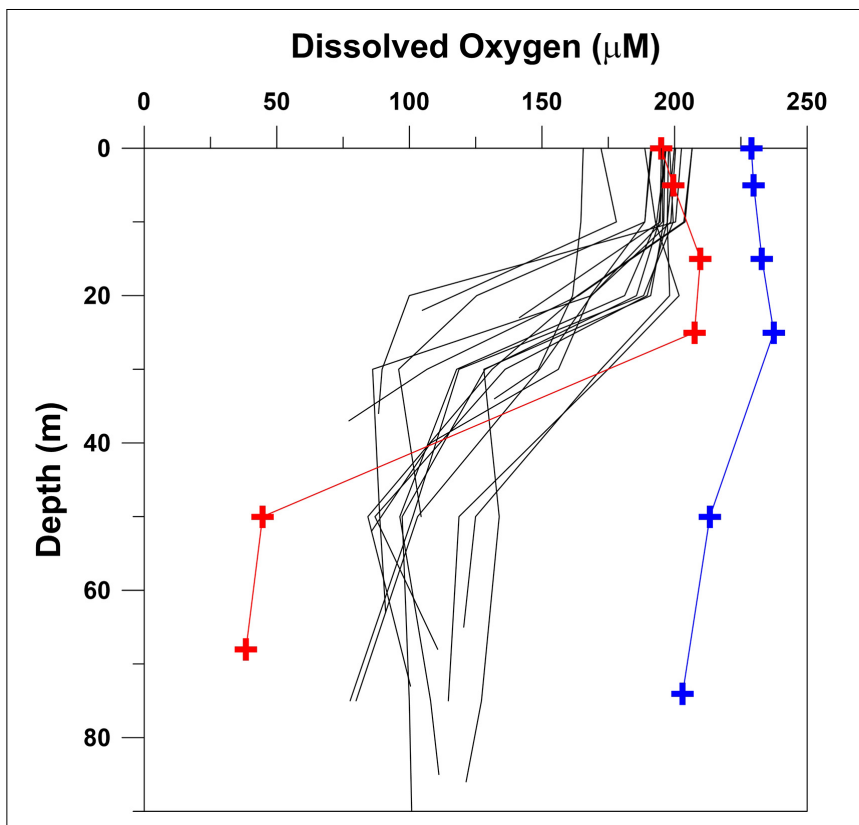

FIGURE 7 | Comparison of oxygen data in the Persian Gulf collected east of longitude $51.77^{\circ} \mathrm{E}$ during a cruise of R.V. Lesnoye in September 1968 (black profiles) with measurements made north of the Qatar peninsula during cruises of R.V. Mukhtabar al-Bahr in September-October 2000 (red symbols) and February-March 2001 (blue symbols).

scale shift, oxygen profiles at a number of stations sampled by the R.V. Lesnoye in September 1968 in the southern Gulf (Table 1) have also been included in Figure 7. The Lesnoye data set is the only historical data set generated in summer from this region. It is clear that summer-time oxygen depletion in the central Gulf also occurred in the 1960s, but not to the extent observed by Al-Ansari et al. (2015). At the same time near-surface oxygen values in the summer of 2000 were higher than most values in 1968, a tell-tale sign of eutrophication. Extrapolating their highly limited data, Al-Ansari et al. (2015) estimated the area of the "hypoxic" zone to exceed 7,000 $\mathrm{km}^{2}$. Obviously, this estimate suffers from large uncertainty; nevertheless, in all likelihood the emergence of hypoxia in Qatari EEZ appears to be linked to human activities. If so, it is expected that further declines in oxygen should have occurred over the past two decades, underlining the urgent need for generation of new data from the southern Gulf, especially in summer.

\section{Andaman Sea}

A large number of oxygen profiles were generated from the Andaman Sea during the International Indian Ocean Expedition (IIOE), which can be used as the baseline for detecting and quantifying changes, if any, that have occurred in the region since then. These data, extracted from the WOD-NOAA database for the period 1961-1964 (Table 1), were compared with the latest publicly available data. Unfortunately, as the entire Andaman Sea falls within the EEZs of surrounding countries, it is not easily accessible for international exploration. The Knorr cruise that sampled WOCE I01 Line was an exception. Not only are there no 
more recent bottle data from this region in the global data base, there have also not been any BIOARGO floats deployments in the Andaman Sea so far.

While the Knorr data came from a zonal transect, the IIOE stations were located over a wide latitudinal range. While this would not make a difference for the data below the sill depth $(\sim 1.4 \mathrm{~km})$ since the deep water is exceedingly homogenous throughout the basin, it would matter for shallower depths because oxygen concentrations below the surface mixed layer and above the sill depth decrease steadily northward (Wyrtki, 1971). This is reflected in the larger scatter of oxygen concentrations at shallower depths, especially close to the oxygen minimum, in Figure 8, where all IIOE data are plotted along with the Knorr data. It must also be pointed out that the IIOE observations covered different seasons (Table 1). However, as stated earlier, one of the most distinguishing features of the NEIO, including the Andaman Sea, is the extremely strong stratification in the upper water column arising from the large river runoff and local precipitation. The moderate winter cooling is unable to overcome this barrier, and so in contrast with the NWIO, subsurface layers in the NEIO are not affected by seasonal mixing and are not ventilated by locally formed water masses (Naqvi et al., 2006). The isolation of waters below the pycnocline, including the $\mathrm{OMZ}$, is reflected by low penetration of anthropogenic tracers like tritium and chlorofluorocarbons (Rao et al., 1994; Talley, 2013). Therefore, while no seasonal changes are expected to occur in deep waters, such changes are also most probably negligible within the OMZ. In general, oxygen concentrations measured on the Knorr cruise are slightly lower than those recorded in the early 1960s. At depths $>1.5 \mathrm{~km}$ the mean $\pm \mathrm{SD}$ of Knorr oxygen data is $78.40 \pm 1.37 \mu \mathrm{M}$ $\left(1.76 \pm 0.03 \mathrm{ml} \mathrm{l}^{-1}\right)$ as compared to $79.73 \pm 2.77 \mu \mathrm{M}$ $\left(1.79 \pm 0.06 \mathrm{ml} \mathrm{l}^{-1}\right)$ for the IIOE data. The difference, although small, is statistically significant (2-tailed Student $t$-test, $p=0.000564)$. A similar comparison was also made for data from the OMZ, but only within the depth range 150-350 m and from stations located between latitudes $9^{\circ} \mathrm{N}$ and $11^{\circ} \mathrm{N}$. The mean $\pm \mathrm{SD}$ values for the Knorr data $-22.52 \pm 2.51 \mu \mathrm{M}$ $\left(0.50 \pm 0.06 \mathrm{ml} \mathrm{l}^{-1}\right)$ - were even more significantly lower (twotailed Student $t$-test, $p<0.00001)$ than those for the IIOE data $28.88 \pm 3.80 \mu \mathrm{M}\left(0.65 \pm 0.09 \mathrm{ml} \mathrm{l}^{-1}\right)$. However, it may be pointed out that while on the IIOE cruises Winkler titrations were carried out manually with visual end point detection, an automated procedure involving photometric end-point detection was followed on the Knorr. It has been pointed out earlier that at oxygen concentrations approaching zero, automated titrations yield consistently lower values (by $\sim 0.04 \mathrm{ml} \mathrm{l}^{-1}, 1.79 \mu \mathrm{M}$ ) than manual titrations (Banse et al., 2014). However, even after considering this potential offset (i.e., subtracting it from each value for the IIOE data), the Knorr values would still be significantly lower $(p<0.00001)$. Thus, it appears that the core of the Andaman Sea OMZ had already lost small but significant amount of oxygen by the mid-1990s. Accordingly, mean water column oxygen inventory, computed to a constant depth of 3,000 $\mathrm{m}$ for the deepest part of the Andaman Basin, decreased from $206.9 \mathrm{~mol} \mathrm{~m}^{-2}(n=5)$ during 1961-1964 to $199.9 \mathrm{~mol} \mathrm{~m}^{-2}$ $(n=2)$ in 1995 .

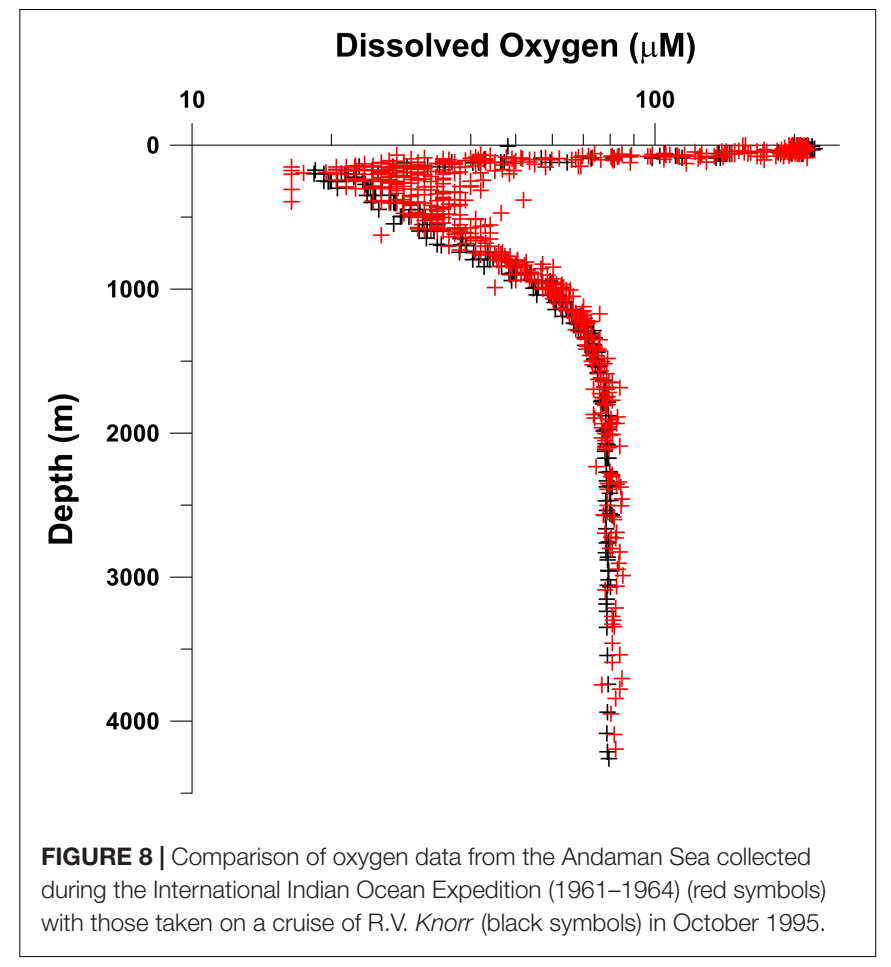

\section{Coastal "Dead Zones"}

Among the hundreds of hypoxic "dead zones" that are known to have developed globally in coastal waters over the past few decades due to human activities, mainly eutrophication (Diaz and Rosenberg, 2008), there are only two confirmed cases from the Indian Ocean's marginal seas (Breitburg et al., 2018). The most severe oxygen depletion in this category has been reported from the vicinity of Jeddah, the largest city along the Red Sea shores having a population of around 3 million. Three coastal lagoons in this area - Al-Shabab, Al-Arbaeen and Al-Salam receive large quantities of treated or untreated sewage discharge from Jeddah City, which in conjunction with restricted flushing creates low oxygen conditions. Hypoxic/anoxic conditions in the Al-Shabab and Al-Arbaeen lagoons have been described in detail by Orif et al. (2017). Although similar data from the water column are not available from the Al-Salam lagoon, considering the sedimentary characteristics described by AbuZied and Orif (2019) together with the waste-water runoff and organic matter/nutrients loadings, hypoxia probably affects this lagoon as well. Oxygen concentrations have been observed to fall to hypoxic level of $63 \mu \mathrm{M}$ in Al-Shahab lagoon, and water in the Arbaeen lagoon turns fully anoxic below $0.5 \mathrm{~m}$ with large buildup of $\mathrm{H}_{2} \mathrm{~S}$ (up to $55.5 \mu \mathrm{M}$ ). Substantial loss of fixed nitrogen also appears to occur in these lagoons along with huge production of methane, probably in sediments (Orif et al., 2017). In fact, bottom water methane levels in the Al-Arbaeen lagoon (maximum $13.2 \mu \mathrm{M}$ ) are comparable to those recorded in the deep anoxic basins of Black Sea and Cariaco Basin (Naqvi et al., 2010).

Shorter-lived episodes of deoxygenation have also been reported from coastal waters of Kuwait that receive huge quantities of anthropogenic nutrients and organic matter from 
land. The group of semi-enclosed bays (Kuwait Bay along with the embedded Sulaibikhat Bay and Doha Bay) located at the northwestern extreme of the Persian Gulf receive enormous quantities of sewage and other effluents from Kuwait City and nearby industrial establishments. The region has extensive mudflats that are highly important from the ecological and biogeochemical points of view (Al-Yamani et al., 2004). The conditions within these sediments are strongly reducing (Dr. Turki Al-Said, personal communication). The tidal amplitude is fairly high $(\sim 4 \mathrm{~m})$, and periodic inundation of reducing intertidal sediments probably causes substantial depletion of oxygen in the overlying waters. An analysis of data collected during January 2009-November 2011 at a number of monitoring stations in this area revealed low oxygen saturation (minimum $<39 \%$ ) off Kuwait City, extending from Sulaibikhat Bay to Doha Bay (Al-Mutairi et al., 2015). However, further away from the coast in the center of the Kuwait Bay, monthly sampling at a fixed station (K6, latitude $29.45^{\circ} \mathrm{N}$, longitude $47.967^{\circ} \mathrm{E}$, depth $12 \mathrm{~m}$ ) being carried out since 2004 revealed that bottom water oxygen content has almost always been above $4 \mathrm{mg} \mathrm{l}^{-1}\left(2.8 \mathrm{ml} \mathrm{l}^{-1}\right.$, $125 \mu \mathrm{M}$ ), the nominal threshold for mild hypoxia (Dr. Faiza Al-Yamani, personal communication). However, eutrophication has led to a marked increase in the frequency of algal blooms, including harmful blooms, in Kuwait's waters in recent years (Al-Yamani et al., 2012; Al-Yamani and Naqvi, 2019). There have been instances of fish mortality in Kuwait waters associated with hypoxia as described by Al-Yamani et al. (2020). In one such incident mass mortality of sardines (Sardinella fimbriata) occurred in Ras Al-Adrdh Marina, Salimya, Kuwait on August 10,2005 . As the oxygen content was low throughout the water column $\left[1.26 \mathrm{ml} \mathrm{l}^{-1}(56.23 \mu \mathrm{M}), 1.19 \mathrm{ml} \mathrm{l}^{-1}(53.10 \mu \mathrm{M})\right.$ and $0.70 \mathrm{ml} \mathrm{l}^{-1}(31.24 \mu \mathrm{M}) \mathrm{O}_{2}$ at the surface, mid-depth, and bottom, respectively], hypoxia was considered to be a possible cause of the observed mortality. A similar but more extended mortality episode involving the same fish in the same area took place again in June-July, 2011, during which oxygen concentrations were also quite low (Figure 9A). Fish kills also occurred around the same time further to the south in the Messila Marina where the oxygen level in the upper $1 \mathrm{~m}$ fell to $0.14 \mathrm{ml} \mathrm{l}^{-1}(6.25 \mu \mathrm{M})$. Water discoloration by a bloom of the dinoflagellate Gonyaulax verior was conspicuously seen here. An even more widespread mortality event involving two catfish species, Netuma thalassina and Plicofollis tenuspinus, took place in Kuwait waters - especially in Kuwait Bay - in April-May, 2017. This was also associated with water discoloration due to blooms of potentially harmful raphidophycean flagellate Heterosigma akashiwo and dinoflagellate Karenia papilionacea (known to produce Brevetoxin, a neurotoxin). Oxygen measurements made during this period revealed generally well-oxygenated water column, except in one case where the vertical profile in Shuwaikh Port (Figure 9B) showed almost complete oxygen removal close to the bottom ( $10.5 \mathrm{~m})$ (Al-Yamani et al., 2020). Thus, while oxygen-deficiency may or may not be the cause of the observed fish mortality, it is clearly one of the effects of episodic, excessive phytoplankton production (evident from very high oxygen concentration at the surface in Figure 9B) resulting from nutrient-over enrichment in coastal waters of the Persian Gulf.

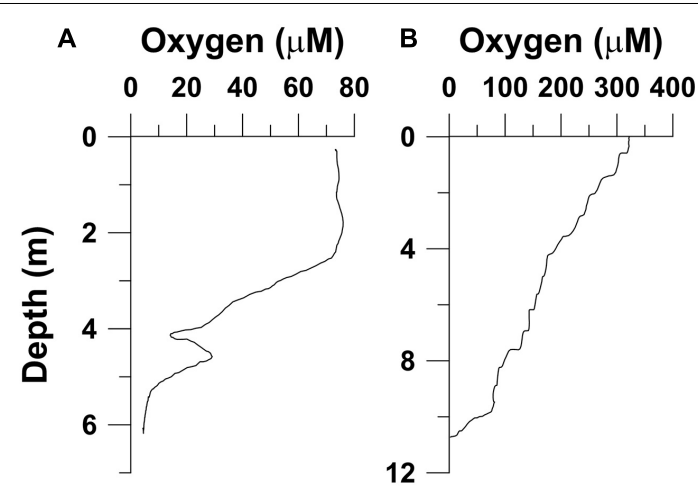

FIGURE 9 | Oxygen profiles at Rescue Station Marina in Salmiya, Kuwait (latitude $29.34^{\circ} \mathrm{N}$, longitude $48.10^{\circ} \mathrm{E}$ ) during a fish kill incident on July 19 , 2011 (A), and in Shuwaikh Port (latitude $29.36^{\circ} \mathrm{N}$, longitude $47.93^{\circ} \mathrm{E}$ ) on April 30, 2017 (B). Redrawn from Al-Yamani et al. (2020).

\section{DISCUSSION}

The results presented above show declining trends in oxygen levels in all three basins. Before discussing their significance it is necessary to address a few issues that have important bearings on the inferences being drawn. First and foremost is the concern about compatibility of oxygen data used. As already discussed, the magnitudes of observed shifts are well beyond potential errors of measurements. The second issue relates to seasonality in oxygen distribution. Again, as pointed out above, seasonality is probably not very pronounced in the deep basins the Red Sea and the Andaman Sea - below the surface layer. Moreover, in the case of the Red Sea the Argo float data cover all seasons and the range of values recorded by the floats is well below oxygen concentrations measured in 1983. On the other hand, seasonal changes are expected to be quite large in the Persian Gulf. This is, in fact, apparent from the data from the Qatari EEZ in the central Gulf taken during two consecutive summer and winter periods in 2000-2001, with the subsurface water being expectedly more oxygen depleted in summer (Figure 7). However, for the same month (September), bottom water oxygen concentrations were much lower in 2000 as compared to those in 1968. Thus, after taking into account the seasonality, the results strongly indicate increasing summertime deoxygenation in the Persian Gulf. The third issue pertains to shifting baselines. That is, it is not known to what extent the data used as reference (collected in May 1983 in the case of Red Sea, in September 1968 in the case of the Persian Gulf. and during 1961-1964 in the case of the Andaman Sea) had already been anthropogenically impacted. Such an impact is expected to have been largest in the Persian Gulf that is quite shallow and small in size and has been subjected to human activities for a long time, especially after the discovery of oil and the wealth and "development" it brought to the region around the middle of the last century. However, even if the data used as reference might not represent "pristine" conditions, the comparisons with more recent measurements still yield reliable trends of change. 
It is also not clear if or to what extent the observed deoxygenation trends are contributed by long-term natural variability, an inherent problem with any two-point comparison, but one that unfortunately cannot be addressed with the available data. It may be pointed out that there is evidence for existence of such variability in the Red Sea on the decadal scale. Satellite remote-sensed SST data have revealed a warming trend with values ranging from 0.17 to $0.45^{\circ} \mathrm{C}$ decade $^{-1}$ across the Red Sea basin for the period 1982-2015 (Chaidez et al., 2017). However, the analysis of available water column data for the period 19582017 showed a more complex pattern - a steady decrease in SST from the 1960s up to the mid-1980s and an increasing trend thereafter (Agulles et al., 2020). It has been suggested that the long-term SST oscillations may be associated with the Atlantic Multidecadal Oscillation (AMO) and that the abovementioned high warming rates over the past three decades or so are probably a combined effect of global warming and a positive phase of natural SST oscillations (Krokos et al., 2019). According to Krokos et al. (2019) the cooling AMO phase may offset the global warming related SST increase in the Red Sea in the future. What is really intriguing is that the temporal trends in subsurface water temperatures appear to be decoupled to the SST trend, showing an overall cooling trend in deep waters during 19582017 (Agulles et al., 2020). The data compiled by Agulles et al. (2020) show that since the time of the Sagar Kanya cruise the 100-500 m layer cooled up to mid 1990s and has been warming thereafter; the deeper waters showed a similar pattern, except that the minimum occurred a little later (in the late 1990s) and the subsequent warming has been more subdued. It is hard to reconcile the observed deoxygenation in deep waters of the Red Sea with these temperature variations, but it is clear that the oxygen decrease cannot be simply attributed to decreased solubility in warmer water.

Interannual and decadal-scale variability in oxygen forced by regional climate modes (e.g., the Indian Ocean Dipole) has been reported to control the intensity of seasonal anoxia over the western Indian shelf (Vallivattathillam et al., 2017). Such a variability may also occur in the off shore OMZs of the northern Indian Ocean (Rixen et al., 2020), but convincing evidence for this is lacking so far. Nevertheless, even though it is unlikely, one cannot completely rule out such a variability to account for a part of the oxygen declines being reported here.

Deoxygenation in the Mediterranean-type marginal seas is of special significance because of their unusual hydrography and the potential for its impact extending beyond the marginal seas themselves. For example, it has been pointed out by Seibel et al. (2016), who studied the metabolism and hypoxia tolerance of the Euphausiid species Euphausia diomedeae in the Red Sea, that owing to the higher water temperature and consequently elevated oxygen demand even moderate hypoxia may be physiologically more challenging to organisms than more severe hypoxia in colder water. These authors postulated that E. diomedeae in the Red Sea reached the limits of adaptation even though $\mathrm{P}_{\text {crit }}$, the partial pressure of oxygen $\left(\mathrm{PO}_{2}\right)$ below which oxygen consumption rate becomes independent of $\mathrm{PO}_{2}$, occurs deeper $(\sim 270 \mathrm{~m})$ in the water column as compared to the California Current and the eastern tropical Pacific, where waters with more intense oxygen minima are cooler. Changes in oxygen content and temperature will combine to determine the extent of habitat compression of marine organisms in all areas, more so in the Red Sea (Seibel et al., 2016).

Besides impacting local biogeochemistry and ecology, deoxygenation in the Persian Gulf and Red Sea is also expected to affect the intensity and volume of the Arabian Sea OMZ, which is uniquely ventilated by outflows from these regional seas (Naqvi, 2019). These outflows are strongly affected by the climate and local hydrography, particularly temperature (Lachkar et al., 2019). Changes in water temperature in the Red Sea have been discussed above. In the Persian Gulf, analysis of time series data from Kuwait's coastal waters has revealed a long-term warming rate of $0.38^{\circ} \mathrm{C}$ decade $^{-1}$ (Al-Yamani et al., 2017), which is more than thrice the average warming rate $\left(0.11^{\circ} \mathrm{C}\right.$ decade $)$ in the ocean (Rhein et al., 2013). Given the smaller size of the Persian Gulf, and the associated short renewal time, effects of warming of this magnitude are expected to be far more rapidly manifested than in the case of the Red Sea. Model simulations have shown that warming of the Persian Gulf has a particularly strong impact on the volume and intensity of the OMZ as the Persian Gulf Outflow advects right into the core of the OMZ (Codispoti et al., 2001; Lachkar et al., 2019). Warming will make the outflow lighter, thereby causing intensification of the OMZ and the associated denitrification process. However, this response is projected to be non linear as under strong warming (e.g., by $4^{\circ} \mathrm{C}$ ), loss of nitrate in the upper layer caused by denitrification is expected to provide a negative feedback to deoxygenation. The model simulations also suggested a relatively weaker effect of increase in salinity in the Persian Gulf on the Arabian Sea OMZ (Lachkar et al., 2019). Warming of the Red Sea is also projected to lead to intensification of the OMZ, but to a smaller extent and at greater depths; as a result of the latter, the response to temperature increase is also more linear than in the case of the Persian Gulf Outflow. However, as discussed above, there does not seem to be consistent trend of warming in the Red Sea at depths from which the outflow is drawn. A more direct effect of the ongoing deoxygenation in the Persian Gulf and the Red Sea on the Arabian Sea OMZ would be through depression of preformed oxygen contents of the outflowing waters. This is expected to be caused both by a lower solubility of oxygen in warmer and more saline waters and an increase in oxygen demand as a consequence of increased productivity fuelled by anthropogenically supplied nutrients. Recent intensification of OMZ in the Gulf of Oman, which directly receives the outflow from the Persian Gulf, has been reported by Queste et al. (2018). It may be noted that salinity in the northern Persian Gulf has increased, especially during the crucial winter months when the dense water is formed, by as much as 10 (Al-Yamani et al., 2017; Al-Said et al., 2018). The total organic carbon (TOC) content of these waters is quite high (101.0-318.4, mean 161.2 $\mu \mathrm{M}-\mathrm{Al}$-Said et al., 2018). Even higher TOC values (336.7-543.3 $\mu \mathrm{M}$ ) were measured in Kuwait Bay in April 2017 during the phytoplankton bloom mentioned above. Al-Said et al. (2018) proposed that the high oxygen demand arising from elevated TOC may be the principal driver of the emerging hypoxia in the Persian Gulf. They also speculated that the semi-labile portion of the TOC 
that escapes degradation in the water column may be exported to the Arabian Sea by the outflow, potentially contributing further to the intensification of the Arabian Sea OMZ. To what extent similar processes also operate in the Red Sea, where the magnitude of human perturbation is much smaller, still remains to be investigated.

The observed deoxygenation trend within the oxygen minimum in the Andaman Sea is comparable to that reported by Naqvi (2019) for the northern Bay of Bengal, even though in the latter case the most recent data used for the comparison with the IIOE observations came from April 2007. This provides support to the view that the rate of oxygen decline in the Indian Ocean, in general, and in the NEIO, in particular, is smaller than in the OMZs of the Pacific Ocean (Stramma et al., 2008; Schmidtko et al., 2017). The present analysis shows that the trend also extends down to the depth in the NEIO $(1.4 \mathrm{~km})$ from where water in the deep Andaman Basin is derived. The extent to which the modest shift being reported here is caused by warming-related changes in oxygen solubility or circulation, or even increases in oxygen consumption cannot be evaluated with the present data. According to Oschlies (2019) the contribution of lower $\mathrm{O}_{2}$ solubility in seawater arising from global warming to the observed decrease in oceanic $\mathrm{O}_{2}$ inventory is relatively small (15\%), but it could be as much as $50 \%$ in the upper kilometer of the water column. He attributed the majority of the change in deep waters to altered water circulation. The role of warming-induced increase in respiration also appears to be small $(<15 \%)$. However, since the Andaman Sea receives large runoff from Irrawaddy River, and is also a part of a region with some of highest deposition rates of nitrogen from the atmosphere (Duce et al., 2008), an increase in primary productivity and associated organic matter export from the surface as an important contributing factor to the observed change cannot be ruled out. It must be pointed out that the current state-of-the-art models underestimate the extent of ocean deoxygenation as compared to what is inferred from observations (Oschlies et al., 2017), underlining the lack of our understanding of controlling processes.

One important common feature of all three marginal seas is they all contain sensitive tropical ecosystems viz. coral reefs, seagrasses and mangroves. Both naturally- and anthropogenically caused hypoxia may occur in some of these ecosystems. One such instance has been reported by Roik et al. (2016) based on an year-long monitoring of physico-chemical variables, which also involved oxygen measurements with a sensor, at 7.5-9 m in three reefs along a cross-shelf gradient off the Saudi Arabian coast in the central Red Sea. Their results showed considerable onshore-offshore and temporal (diurnal to seasonal) variations with an overall oxygen concentration range of $0.05-6.21 \mathrm{ml} \mathrm{l}^{-1}$

\section{REFERENCES}

Abu-Zied, R. H., and Orif, M. I. (2019). Recent environmental changes of Al-Salam Lagoon as inferred from core sediment geochemistry and benthic foraminifera, Jeddah City, Saudi Arabia. Environ. Earth Sci. 78, 60.

Agulles, M., Jordà, G., Jones, B., Agusti, S., and Duarte, C. M. (2020). Temporal evolution of temperatures in the Red Sea and the Gulf of Aden based on in situ
$(2.2-277.2 \mu \mathrm{M})$. The very low values, occurring more often in, but not confined to, summer and in the nearshore reef (the lowest value was recorded in the offshore reef in winter, however, probably arising from community respiration at night), indicate high vulnerability of such ecosystems to humaninduced deoxygenation. As compared to temperate ecosystems, occurrence of such deoxygenation from tropical ecosystems is probably greatly under-reported globally, and according to one estimate $13 \%$ of all coral ecosystems might have already turned into "dead zones" (Altieri et al., 2017, 2019). The ecosystems of Indian Ocean's marginal seas probably also suffer from such under-reporting. As exemplified by the above mentioned reports from the relatively well-studied coastal waters of Kuwait, this may particularly apply to the entire Persian Gulf, which is one of anthropogenically most impacted marine areas in the world (Sheppard et al., 2010), as well as to the poorly investigated shores of the Andaman Sea. The need for capacity building to adequately address this deficiency cannot be over-emphasized.

\section{DATA AVAILABILITY STATEMENT}

Publicly available datasets were analyzed in this study. Data sources are listed in Table 1.

\section{AUTHOR CONTRIBUTIONS}

The author confirms being the sole contributor of this work and has approved it for publication.

\section{FUNDING}

Salary support provided by CSIR.

\section{ACKNOWLEDGMENTS}

The author expresses his gratitude to Shekhar Mande, Director General, Council of Scientific \& Industrial Research (India) for his support and encouragement. He is grateful to Amit Sarkar for drafting Figures 1, 2, 4, 5, and to Akshay Hegde for extracting the data. Thanks are also due to Faiza Al-Yamani of KISR for making available oxygen data plotted in Figure 9. Bob Diaz and Denise Breitburg kindly allowed access to the global data base on hypoxic zones. This work forms a part of the activities of the Global Ocean Oxygen Network $\left(\mathrm{GO}_{2} \mathrm{NE}\right)$ of the Intergovernmental Oceanographic Commission of UNESCO.

observations (1958-2017). Ocean Sci. 16, 149-166. doi: 10.5194/os-16-1492020

Al-Ansari, E. M. A. S., Rowe, G., Abdel-Moati, M. A. R., Yigiterhan, O., Al-Masalmani, I., Al-Yafei, M. A., et al. (2015). Hypoxia in the central Arabian Gulf exclusive economic zone of Qatar during summer season. Estuar. Coast. Shelf Sci. 159, 60-68. doi: 10.1016/j.ecss.2015. 03.022 
Allen, M., Jackson, J., and Walker, R. (2004). Late Cenozoic reorganization of the Arabia-Eurasia collision and the comparison of short-term and long-term deformation rates. Tectonics 23, TC2008. doi: 10.1029/2003TC001530

Al-Mutairi, N., AbaHussain, A., and El-Battay, A. (2015). Spatial assessment of monitoring network in coastal waters: a case study of Kuwait Bay. Environ. Monit. Assess. 187, 621.

Al-Said, T., Naqvi, S. W. A., Al-Yamani, F., Goncharov, A., and Fernandes, L. (2018). High total organic carbon in surface waters of the northern Arabian Gulf: implications for the oxygen minimum zone of the Arabian Sea. Mar. Poll. Bull. 129, 35-42. doi: 10.1016/j.marpolbul.2018.02.013

Altieri, A. H., Harrison, S. B., Seemann, J., Collin, R., Diaz, R. J., and Knowlton, N. (2017). Tropical dead zones and mass mortalities on coral reefs. Proc. Natl. Acad. Sci. U.S.A. 114, 3660-3665. doi: 10.1073/pnas.1621517114

Altieri, A. H., Nelson, H. R., and Gedan, K. B. (2019). "The significance of ocean deoxygenation for tropical ecosystems - corals, seagrasses and mangroves," in Ocean Deoxygenation: Everyone's Problem. Causes, Impacts, Consequences and Solutions, eds D. Laffoley and J. M. Baxter (Gland: International Union for Conservation of Nature), 401-429.

Al-Yamani, F., and Naqvi, S. W. A. (2019). Chemical oceanography of the Arabian Gulf. Deep Sea Res. II 161, 72-80. doi: 10.1016/j.dsr2.2018.10.003

Al-Yamani, F., Saburova, M., and Polikarpov, I. (2012). A preliminary assessment of harmful algal blooms in Kuwait's marine environment. Aquat. Ecosyst. Health Manag. 15(Suppl. 1), S64-S72.

Al-Yamani, F., Yamamoto, T., Al-Said, T., and Alghunaim, A. (2017). Dynamic hydrographic variations in Northwestern Arabian Gulf over the past three decades: temporal shifts and trends derived from long-term monitoring data. Mar. Poll. Bull. 122, 488-499. doi: 10.1016/j.marpolbul.2017.06.056

Al-Yamani, F. Y., Bishop, J. M., Ramadhan, E., Al-Husaini, M., and Al-Ghadban, A. N. (2004). Oceanographic Atlas of Kuwait's Waters. Kuwait City: Kuwait Institute for Scientific Research.

Al-Yamani, F. Y., Polikarpov, I., and Saburova, M. (2020). Marine life mortalities and Harmful Algal Blooms in the northern Arabian Gulf. Aquat. Ecosyst. Health Manag. 23, 196-209. doi: 10.1080/14634988.2020.1798157

Banse, K., Naqvi, S. W. A., Narvekar, P. V., Postel, J. R., and Jayakumar, D. A. (2014). Oxygen minimum zone of the open Arabian Sea: variability of oxygen and nitrite from daily to decadal timescales. Biogeosciences 11, 2237-2261. doi: 10.5194/bg-11-2237-2014

Bettig, H., and Körtzinger, H. (2015). Tackling oxygen optode drift: Near-surface and in-air oxygen optode measurements on a float provide an accurate in situ reference. J. Atmos. Oceanic Technol. 32, 1536-1543. doi: 10.1175/jtech-d-1400162.1

Breitburg, D., Conley, D. J., Levin, L. A., Oschlies, A., Oschlies, A., Chavez, F. P., et al. (2018). Declining oxygen in the global ocean and coastal waters. Science 359, eaam7240.

Brewer, P. G., and Dyrssen, D. (1985). Chemical oceanography of the Persian Gulf. Prog. Oceanogr. 14, 41-55. doi: 10.1016/0079-6611(85)90004-7

Brewer, P. G., Fleer, A. P., Kadar, S., Shafer, D. K., and Smith, C. L. (1978). Chemical oceanographic data from the Persian Gulf and Gulf of Oman. Woods Hole Oceanogr. Inst. Tech. Rep. 105, 78-37.

Brewin, R. J. W., Raitsos, D. E., Dall'Olmo, G., Zarokanellos, N., Jackson, T., Racault, M.-F., et al. (2015). Regional ocean-colour chlorophyll algorithms for the Red Sea. Rem. Sens. Environ. 165, 64-85. doi: 10.1016/j.rse.2015.04.024

Bristow, L. A., Callbeck, C. M., Larsen, M., Altabet, M. A., Dekaezemacker, J., Forth, M., et al. (2017). $\mathrm{N}_{2}$ production rates limited by nitrite availability in the Bay of Bengal oxygen minimum zone. Nat. Geosci. 10, 24-29. doi: 10.1038/ngeo2847

Broecker, W. S., Toggweiler, J. R., and Takahashi, T. (1980). The Bay of Bengal A major nutrient source for the deep Indian Ocean. Earth Planet. Sci. Lett. 49, 506-512. doi: 10.1016/0012-821x(80)90091-6

Carpenter, J. (1965). The accuracy of the Winkler method for dissolved oxygen analysis. Limnol. Oceanogr. 10, 135-140. doi: 10.4319/lo.1965.10.1.0135

Cember, R. P. (1988). On the sources, formation, and circulation of Red Sea deep water. J. Geophys. Res. 93, 8175-8191. doi: 10.1029/jc093ic07p0 8175

Chaidez, V., Dreano, D., Agusti, S., Duarte, C. M., and Hoteit, I. (2017). Decadal trends in Red Sea maximum surface temperature. Sci. Rep. 7, 1-8.

Chakraborty, A., Nanjundiah, R. S., and Srinivasan, J. (2002). Role of Asian and African orography in Indian summer monsoon. Geophys. Res. Lett. 29, 50.1-50.4. doi: 10.1029/2002GL015522
Cochran, J. R. (2010). Morphology and tectonics of the Andaman Forearc, northeastern Indian Ocean. Geophys. J. Int. 182, 631-651. doi: 10.1111/j.1365246X.2010.04663.x

Codispoti, L. A., Brandes, J. A., Christensen, J. P., Devol, A. H., Naqvi, S. W. A., Paerl, H. W., et al. (2001). The oceanic fixed nitrogen and nitrous oxide budgets: moving targets as we enter the anthropocene. Sci. Mar. 65 (Suppl. 2), 85-105. doi: $10.3989 /$ scimar.2001.65s285

Diaz, R. J., and Rosenberg, R. (2008). Spreading dead zones and consequences for marine ecosystems. Science 321, 926-929. doi: 10.1126/science.1156401

Duce, R. A., LaRoche, J., Altieri, K., Arrigo, K. R., Baker, A. R., Capone, D. G., et al. (2008). Impacts of atmospheric anthropogenic nitrogen on the open ocean. Science 320, 893-897.

El Samra, M. I., and El Gindy, A. A. H. (1990). Vertical distribution and interrelations of oxygen and nutrients in the Arabian Gulf and the Gulf of Oman in summer. Qatar Univ. Sci. Bull. 10, 445-464.

Grasshoff, K. (1975). "The hydrochemistry of landlocked basins and fjords," in Chemical Oceanography, Vol. 2, eds J. P. Riley and G. Skirrow (London: Academic Press), 455-597.

Grasshoff, K. (1976). Review of Hydrographical and Productivity Conditions in the Gulf Region, Marne Sciences in the Gulf Area, Vol. 26. Paris: UNESCO Technical Papers in Marine Science, 39-62.

Hashimoto, S., Tsujimoto, R., Maeda, M., Ishimaru, T., Yoshida, J., Takasu, Y., et al. (1998). "Distribution of nutrient, nitrous oxide and chlorophyll a of RSA: extremely high ratios of nitrite to nitrate in whole water column," in Offshore Environment of the ROPME Sea Area After the War-Related Oil Spill: Results of the 1993 - 94 Umitaka-Maru Cruises, (Tokyo: Terra Science), 99-124.

Ittekkot, V., Haake, B., Bartsch, M., Nair, R. R., and Ramaswamy, V. (1992). "Organic carbon removal in the sea: the continental connection," in Upwelling Systems: Evolution Since the Early Miocene, Vol. 64, eds C. P. Summerhayes, W. L. Prell, and K.-C. Emeis (London: Geological Society of London), 167-176. doi: 10.1144/gsl.sp.1992.064.01.11

Jithin, A. K., and Francis, P. A. (2020). Role of internal tide mixing in keeping the deep Andaman Sea warmer than the Bay of Bengal. Sci. Rep. 10:11982. doi: 10.1038/s41598-020-68708-6

Johns, W. E., Yao, F., Olson, D. B., Josey, S. A., Grist, J. P., and Smeed, D. A. (2003). Observations of seasonal exchange through the Straits of Hormuz and the inferred heat and freshwater budgets of the Persian Gulf. J. Geophys. Res. 108, 3391. doi: 10.1029/2003JC001881

Krokos, G., Papadopoulos, V. P., Sofianos, S. S., Ombao, H., Dybczak, P., and Hoteit, I. (2019). Natural climate oscillations may counteract Red Sea warming over the coming decades. Geophys. Res. Lett. 46, 3454-3461. doi: 10.1029/ $2018 \mathrm{gl081397}$

Lachkar, Z., Levy, M., and Smith, K. S. (2019). Strong intensification of the Arabian Sea oxygen minimum zone in response to Arabian Gulf warming. Geophys. Res. Lett. 46, 5420-5429. doi: 10.1029/2018gl081631

Lambeck, K., Purcell, A., Flemming, N. C., Vita-Finzi, C., Alsharekh, A. M., and Bailey, G. N. (2011). Sea level and shoreline reconstructions for the Red Sea: Isostatic and tectonic considerations and implications for hominin migration out of Africa. Quat. Sci. Rev. 30, 3542-3574. doi: 10.1016/j.quascirev.2011. 08.008

Maillard, C., and Soliman, G. (1986). Hydrography of the Red Sea and exchanges with the Indian Ocean in summer. Oceanol. Acta 9, 249-269.

Mantyla, A. W., and Reid, J. L. (1995). On the origins of deep and bottom waters of the Indian Ocean. J. Geophys. Res. 100, 2417-2439. doi: 10.1029/94jc02564

Morcos, S. A. (1970). Physical and chemical oceanography of the Red Sea. Oceanogr. Mar. Biol. Ann. Rev. 8, 73-202.

Murray, S. P., and Johns, W. (1997). Direct observations of seasonal exchange through the Bab el Mandab Strait. Geophys. Res. Lett. 24, 2557-2560. doi: $10.1029 / 97 \mathrm{gl02741}$

Naqvi, S. W. A. (2019). "Evidence for ocean deoxygenation and its patterns: Indian Ocean," in Ocean Deoxygenation: Everyone's Problem. Causes, Impacts, Consequences and Solutions, eds D. Laffoley and J. M. Baxter (Gland: International Union for Conservation of Nature), 51-71.

Naqvi, S. W. A., Bange, H. W., Farias, L., Monteiro, P. M. S., Scranton, M. I., and Zhang, J. (2010). Marine hypoxia/anoxia as a source of $\mathrm{CH}_{4}$ and $\mathrm{N}_{2} \mathrm{O}$. Biogeosciences 7, 2159-2190.

Naqvi, S. W. A., Charles, C. D., and Fairbanks, R. G. (1994). Carbon and oxygen isotopic records in benthic foraminifera from the Northeast Indian Ocean: 
implications on glacial interglacial atmospheric $\mathrm{CO}_{2}$ changes. Earth Planet. Sci. Lett. 121, 110.

Naqvi, S. W. A., Hansen, H. P., and Kureishy, T. W. (1986). Nutrient uptake and regeneration ratios in the Red Sea with reference to the nutrient budgets. Oceanolog. Acta 9, 271-275.

Naqvi, S. W. A., Narvekar, P. V., and Desa, E. (2006). "Coastal biogeochemical processes in the North Indian Ocean (14, SW)," in The Sea, Vol. 14, eds A. Robinson and K. Brink (Cambridge, MA: Harvard University Press), 723-780.

Naqvi, S. W. A., Shailaja, M. S., Kumar, M. D., and Sen Gupta, R. (1996). Respiration rates in subsurface waters of the northern Indian Ocean: evidence for low decomposition rates of organic matter within the water column in the Bay of Bengal. Deep Sea Res. II 43, 73-81. doi: 10.1016/0967-0645(95) 00080-1

Orif, M. I., Kavil, Y. N., Kelassanthodi, R., Al-Farawati, R., and Al Zobidi, M. I. (2017). Dissolved methane and oxygen depletion in the two coastal lagoons, Red Sea. Indian J. Geo-Mar. Sci. 46, 1287-1297.

Oschlies, A. (2019). "Ocean deoxygenation from climate change," in Ocean Deoxygenation: Everyone's Problem. Causes, Impacts, Consequences and Solutions, eds D. Laffoley and J. M. Baxter (Gland: International Union for Conservation of Nature), 105-116.

Oschlies, A., Duteil, O., Getzlaff, J., Koeve, W., Landolfi, A., and Schmidtko, S. (2017). Patterns of deoxygenation: sensitivity to natural and anthropogenic drivers. Philos. Trans. R. Soc. A 375, 2102.

Plahn, O., Baschek, B., Badewien, T. H., Walter, M., and Rhein, M. (2002). Importance of the Gulf of Aqaba for the formation of bottom water in the Red Sea. J. Geophys. Res. 107, 22-1-22-18. doi: 10.1029/2000jc000342

Pous, S., Pascal, L., and Xavier, C. (2015). A model of the general circulation in the Persian Gulf and in the Strait of Hormuz: interseasonal to interannual variability. Cont. Shelf. Res. 94, 55-90. doi: 10.1016/j.csr.2014.12.008

Prasad, T. G. (2004). A comparison of mixed-layer dynamics between the Arabian Sea and Bay of Bengal: One-dimensional model results. J. Geophys. Res. 109, C03035. doi: 10.1029/2003JC002000

Queste, B. Y., Vic, C., Heywood, K. J., and Piontkovski, S. A. (2018). Physical controls on oxygen distribution and denitrification potential in the North West Arabian Sea. Geophys. Res. Lett. 45, 4143-4152. doi: 10.1029/2017gl07 6666

Rao, C. K., Naqvi, S. W. A., Kumar, M. D., Varaprasad, S. J. D., Jayakumar, D. A., George, M. D., et al. (1994). Hydrochemistry of the Bay of Bengal: possible reasons for a different water column cycling of carbon and nitrogen from the Arabian Sea. Mar. Chem. 47, 290.

Rhein, M., Qin, D., Plattner, G. K., Tignor, M. M. B., Allen, S. K., Boschung, J., et al. (2013). "Observations: Ocean," in Climate Change 2013: The Physical Science Basis. Contribution of Working Group I to the Fifth Assessment Report of the Intergovernmental Panel on Climate Change, ed. T. F. Stocker (Cambridge: Cambridge University Press), 255-315.

Rixen, T., Cowie, G., Gaye, B., Goes, J., do Rosário Gomes, H., Hood, R. R., et al. (2020). Reviews and syntheses: present, past, and future of the oxygen minimum zone in the northern Indian Ocean. Biogeosciences 17, 6051-6080. doi: 10.5194/bg-17-6051-2020

Rixen, T., Gaye, B., Emeis, K.-C., and Ramaswamy, V. (2019). The ballast effect of lithogenic matter and its influences on the carbon fluxes in the Indian Ocean. Biogeosciences 16, 485-503. doi: 10.5194/bg-16-485-2019

Roik, A., Röthig, T., Roder, C., Ziegler, M., Kremb, S. G., and Voolstra, C. R. (2016). Year-long monitoring of physico-chemical and biological variables provide a comparative baseline of coral reef functioning in the Central Red Sea. PLoS One 11:e0163939. doi: 10.1371/journal.pone.0163939

Sarma, V. V. S. S., and Narvekar, P. V. (2001). A study on inorganic carbon components in the Andaman Sea during the post monsoon season. Oceanol. Acta 24, 125-134. doi: 10.1016/s0399-1784(00)01133-6

Scaife, G., Spectrum, and Billings, A. (2010). Andaman Basin. Available online at: tGEOEXPRO, 7, https://www.geoexpro.com/articles/2010/05/andaman-basin (accessed October 20, 2020)

Schmidtko, S., Stramma, L., and Visbeck, M. (2017). Decline in global oceanic oxygen content during the past five decades. Nature 542, 335. doi: 10.1038/ nature 21399

Seibel, B. A., Schneider, J. L., Kaartvedt, S., Wishner, H. F., and Daly, K. L. (2016). Hypoxia tolerance and metabolic suppression in oxygen minimum zone Euphausiids: implications for ocean deoxygenation and biogeochemical cycles. Integr. Comp. Biol. 56, 510-523. doi: 10.1093/icb/icw091
Sen Gupta, R., Moraes, C., George, M. D., Kureishy, T. W., Noronha, R. J., and Fondekar, S. P. (1981). Chemistry and hydrography of the Andaman Sea. Indian J. Mar. Sci. 10, 228-233.

Shenoi, S. S. C., Shetye, S. R., and Shankar, D. (2002). Differences in heat budgets of the near-surface Arabian Sea and Bay of Bengal: Implications for the summer monsoon. J. Geophys. Res 107, 5-1-5-14. doi: 10.1029/2000JC000679

Sheppard, C. R. C., Al-Husiani, M., Al-Jamali, F., Al-Yamani, F., Baldwin, R., Bishop, J., et al. (2010). The Gulf: a young sea in decline. Mar. Pollut. Bull. 60, $13-38$.

Sofianos, S. S., and Johns, W. E. (2002). An Oceanic general circulation model (OGCM) investigation of the Red Sea circulation. 1. Exchange between the Red Sea and the Indian Ocean. J. Geophys. Res 107, 3196. doi: 10.1029/ 2001JC001185

Sofianos, S. S., and Johns, W. E. (2003). An Oceanic General Circulation Model (OGCM) investigation of the Red Sea circulation: 2. Three dimensional circulation in the Red Sea. J. Geophys. Res 108, 3066.

Sofianos, S. S., and Johns, W. E. (2007). Observations of the summer Red Sea circulation. J. Geophys. Res 112, C06025. doi: 10.1029/2006JC003886

Sofianos, S. S., Johns, W. E., and Murray, S. P. (2002). Heat and freshwater budgets in the Red Sea from direct observations at Bab el Mandeb. Deep-Sea Res. II 49, 1323-1340. doi: 10.1016/s0967-0645(01)00164-3

Stern, R. J., and Johnson, P. (2010). Continental lithosphere of the Arabian Plate: a geologic, petrologic, and geophysical synthesis. Earth Sci. Rev. 101, 29-67. doi: 10.1016/j.earscirev.2010.01.002

Stramma, L., Johnson, G. C., Sprintall, J., and Mohrholz, V. (2008). Expanding oxygen-minimum zones in the tropical oceans. Science 320, 655-658. doi: $10.1126 /$ science. 1153847

Swift, S. A., and Bower, A. S. (2003). Formation and circulation of dense water in the Persian/Arabian Gulf. J. Geophys. Res. 108, 3004. doi: 10.1029/ 2002JC001360

Talley, L. D. (2013). Hydrographic Atlas of the World Ocean Circulation Experiment (WOCE) Vol. 4: Indian Ocean, eds M. Sparrow, P. Chapman, and J. Gould (Southampton: International WOCE Project Office). doi: 10.21976/C61595

Thamdrup, B., Dalsgaard, T., and Revsbech, N. P. (2012). Widespread functional anoxia in the oxygen minimum zone of the Eastern South Pacific. Deep Sea Res. I 65, 36-45. doi: 10.1016/j.dsr.2012.03.001

Vallivattathillam, P., Iyyappan, S., Lengaigne, M., Ethé, C., Vialard, J., Levy, M., et al. (2017). Positive Indian Ocean Dipole events prevent anoxia off the west coast of India. Biogeosciences 14, 1541-1559. doi: 10.5194/bg-14-1541-2017

Weiss, R. F., Broecker, W. S., Craig, H., and Spencer, D. (1983). GEOSECS Indian Ocean Expedition, vol. 5, Hydrographic Data. Washington, DC: National Science Foundation, 48.

Winkler, L. W. (1888). Die bestimmung des in Wasser gelösten sauerstoffes. Ber. Dtsch. Chem. Ges. 21, 2843-2854. doi: 10.1002/cber.188802102122

Woelk, S., and Quadfasel, D. (1996). Renewal of deep water in the Red Sea during 1982-1987. J. Geophys. Res. 101, 18155-18165. doi: 10.1029/96jc01148

Wyrtki, K. (1971). Oceanographic Atlas of the International Indian Ocean Expedition. Washington, DC: National Science Foundation, 531.

Wyrtki, K. (1974). "On the Deep Circulation of the Red Sea" in L'oceanographie Physique de la Mer Rouge. Paris: Centre national pour l'Exploitation des Oceans, 135-163.

Yao, F., Hoteit, I., Pratt, L. J., Bower, A. S., Köhl, A., Gopalakrishnan, G., et al. (2014b). Seasonal overturning circulation in the Red Sea: 2 . Winter circulation. J. Geophys. Res. 119, 2263-2289. doi: 10.1002/2013jc009331

Yao, F., Hoteit, I., Pratt, L. J., Bower, A. S., Zhai, P., Köhl, A., et al. (2014a). Seasonal overturning circulation in the Red Sea: 1 . Model validation and summer circulation. J. Geophys. Res. 119, 2238-2262. doi: 10.1002/2013jc00 9004

Conflict of Interest: The author declares that the research was conducted in the absence of any commercial or financial relationships that could be construed as a potential conflict of interest.

Copyright $(2021$ Naqvi. This is an open-access article distributed under the terms of the Creative Commons Attribution License (CC BY). The use, distribution or reproduction in other forums is permitted, provided the original author(s) and the copyright owner(s) are credited and that the original publication in this journal is cited, in accordance with accepted academic practice. No use, distribution or reproduction is permitted which does not comply with these terms. 